\title{
Article \\ Carbon Availability and Nitrogen Mineralization Control Denitrification Rates and Product Stoichiometry during Initial Maize Litter Decomposition
}

\author{
Pauline Sophie Rummel ${ }^{1, *(\mathbb{D})}$, Reinhard Well ${ }^{2}$, Johanna Pausch ${ }^{3}$, Birgit Pfeiffer ${ }^{1,4}$ and Klaus Dittert ${ }^{1}$ \\ 1 Section of Plant Nutrition and Crop Physiology, Department of Crop Science, University of Göttingen, \\ 37073 Göttingen, Germany; Birgit.Pfeiffer@biologie.uni-goettingen.de (B.P.); \\ klaus.dittert@agr.uni-goettingen.de (K.D.) \\ 2 Thünen Institute of Climate-Smart Agriculture, Federal Research Institute for Rural Areas, \\ Forestry and Fisheries, 38116 Braunschweig, Germany; reinhard.well@thuenen.de \\ 3 Agroecology, Faculty for Biology, Chemistry, and Earth Sciences, University of Bayreuth, \\ 95447 Bayreuth, Germany; Johanna.Pausch@uni-bayreuth.de \\ 4 Department of Genomic and Applied Microbiology, Institute of Microbiology and Genetics, \\ University of Göttingen, 37073 Göttingen, Germany \\ * Correspondence: pauline.rummel@uni-goettingen.de
}

check for updates

Citation: Rummel, P.S.; Well, R.; Pausch, J.; Pfeiffer, B.; Dittert, K. Carbon Availability and Nitrogen Mineralization Control

Denitrification Rates and Product Stoichiometry during Initial Maize Litter Decomposition. Appl. Sci. 2021, 11, 5309. https://doi.org/10.3390/ app11115309

Academic Editor: Micòl Mastrocicco

Received: 16 April 2021

Accepted: 2 June 2021

Published: 7 June 2021

Publisher's Note: MDPI stays neutral with regard to jurisdictional claims in published maps and institutional affiliations.

Copyright: (c) 2021 by the authors. Licensee MDPI, Basel, Switzerland. This article is an open access article distributed under the terms and conditions of the Creative Commons Attribution (CC BY) license (https:// creativecommons.org/licenses/by/ $4.0 /)$.

\begin{abstract}
Returning crop residues to agricultural fields can accelerate nutrient turnover and increase $\mathrm{N}_{2} \mathrm{O}$ and $\mathrm{NO}$ emissions. Increased microbial respiration may lead to formation of local hotspots with anoxic or microoxic conditions promoting denitrification. To investigate the effect of litter quality on $\mathrm{CO}_{2}, \mathrm{NO}, \mathrm{N}_{2} \mathrm{O}$, and $\mathrm{N}_{2}$ emissions, we conducted a laboratory incubation study in a controlled atmosphere $\left(\mathrm{He} / \mathrm{O}_{2}\right.$, or pure $\mathrm{He}$ ) with different maize litter types (Zea mays L., young leaves and roots, straw). We applied the $\mathrm{N}_{2} \mathrm{O}$ isotopocule mapping approach to distinguish between $\mathrm{N}_{2} \mathrm{O}$ emitting processes and partitioned the $\mathrm{CO}_{2}$ efflux into litter- and soil organic matter (SOM)-derived $\mathrm{CO}_{2}$ based on the natural ${ }^{13} \mathrm{C}$ isotope abundances. Maize litter increased total and $\mathrm{SOM}$ derived $\mathrm{CO}_{2}$ emissions leading to a positive priming effect. Although $\mathrm{C}$ turnover was high, $\mathrm{NO}$ and $\mathrm{N}_{2} \mathrm{O}$ fluxes were low under oxic conditions as high $\mathrm{O}_{2}$ diffusivity limited denitrification. In the first week, nitrification contributed to $\mathrm{NO}$ emissions, which increased with increasing net $\mathrm{N}$ mineralization. Isotopocule mapping indicated that bacterial processes dominated $\mathrm{N}_{2} \mathrm{O}$ formation in litter-amended soil in the beginning of the incubation experiment with a subsequent shift towards fungal denitrification. With onset of anoxic incubation conditions after 47 days, $\mathrm{N}$ fluxes strongly increased, and heterotrophic bacterial denitrification became the main source of $\mathrm{N}_{2} \mathrm{O}$. The $\mathrm{N}_{2} \mathrm{O} /\left(\mathrm{N}_{2} \mathrm{O}+\mathrm{N}_{2}\right)$ ratio decreased with increasing litter $\mathrm{C}: \mathrm{N}$ ratio and $\mathrm{C}_{\mathrm{org}}: \mathrm{NO}_{3}{ }^{-}$ratio in soil, confirming that the ratio of available $\mathrm{C}: \mathrm{N}$ is a major control of denitrification product stoichiometry.
\end{abstract}

Keywords: fungal denitrification; nitrification; isotopocules; priming effect; nitric oxide; nitrous oxide; dinitrogen; greenhouse gas; decomposition

\section{Introduction}

Returning of crop residues is a common agricultural management strategy to prevent nutrient losses and to increase soil fertility. However, acceleration of $\mathrm{N}$ and $\mathrm{C}$ cycling processes often lead to increased losses of climate-relevant gases.

Addition of plant litter to soils has been proven to increase $\mathrm{CO}_{2}$ and $\mathrm{N}_{2} \mathrm{O}$ emissions over a vast range of soil conditions and litter types [1-4]. Upon degradation, plant litter provides nutrients for decomposing and denitrifying microorganisms. Thus, variations in $\mathrm{N}_{2} \mathrm{O}$ emissions have often been related to litter quality, especially the $\mathrm{C}: \mathrm{N}$ ratio $[1,2]$. For litter with $\mathrm{C}: \mathrm{N}<25: 1$, mineralization increases soil $\mathrm{NO}_{3}{ }^{-}$content leading to increased denitrification [5,6], while for $\mathrm{C}: \mathrm{N}>25: 1, \mathrm{~N}$ is immobilized by soil microorganisms to decompose litter $\mathrm{C}$ compounds [7] and restricts $\mathrm{N}_{2} \mathrm{O}$ emissions [8]. When litter quality 
was analyzed in more detail, easily degradable fractions explained a large share of the variability of $\mathrm{N}_{2} \mathrm{O}$ emissions $[9,10]$, while the lignin content was not relevant [11,12]. Recent studies confirm that the quality of $\mathrm{C}$ compounds (especially water-soluble $\mathrm{C}$ ) from litter is a main driver of denitrification after litter addition $[13,14]$.

Easily degradable $\mathrm{C}$ compounds (e.g., sugars, proteins, amino acids, and carbohydrates) control litter decomposition dynamics in the initial phase and subsequent $\mathrm{CO}_{2}$ efflux from soils $[4,15,16]$. Furthermore, the quality of organic substrates affects decomposition of soil organic matter (SOM) [17]. Readily accessible high-quality substrates increase SOM decomposition, leading to a positive priming effect in soils $[18,19]$. When litter and SOM turnover are increased after litter addition, microbial $\mathrm{O}_{2}$ demand increases with increasing microbial respiration. This may lead to formation of local hotspots with anoxic or microoxic conditions providing favorable conditions for denitrifying soil microorganisms [20]. Accordingly, a recent study reported the highest denitrification-derived $\mathrm{N}_{2} \mathrm{O}$ losses in soils with high SOM priming after addition of labile $C$ substrates (glucose, vanillin) [21]. However, further studies with plant residues are necessary to better understand the interactions between $C$ turnover and denitrification.

The aim of this study was to investigate the effect of litter C quality and SOM turnover on denitrification. We anticipate that increased SOM turnover after litter addition promotes the formation of anoxic hotspots for denitrification and expect higher litter and SOM turnover from litter with high degradability. Thus, we hypothesize that (i) $\mathrm{N}_{2} \mathrm{O}$ fluxes from denitrification increase when $\mathrm{C}$ turnover from litter and SOM is high, leading to (ii) higher $\mathrm{N}_{2} \mathrm{O}+\mathrm{N}_{2}$ losses when litter with a high share of easily degradable $\mathrm{C}$ is added, while (iii) the $\mathrm{N}_{2} \mathrm{O} /\left(\mathrm{N}_{2} \mathrm{O}+\mathrm{N}_{2}\right)$ ratio is controlled by the availability of $\mathrm{C}_{\text {org }}$ in relation to $\mathrm{NO}_{3}{ }^{-}$.

Therefore, we setup a laboratory incubation experiment in an artificial $\mathrm{N}_{2}$-free atmosphere under fully controlled conditions. We compared different types of maize litter (fresh leaves and roots, straw) and investigated the effect of litter quality on total $\mathrm{CO}_{2}$, $\mathrm{NO}, \mathrm{N}_{2} \mathrm{O}$, and $\mathrm{N}_{2}$ emissions. To trace maize litter (C4 plant) and SOM turnover, we used a grassland soil whose organic $\mathrm{C}$ originates solely from $\mathrm{C} 3$ vegetation and partitioned the $\mathrm{CO}_{2}$ efflux into its sources (i.e., litter- and SOM-derived $\mathrm{CO}_{2}$ ) based on the natural ${ }^{13} \mathrm{C}$ isotope abundances. In addition, we analyzed the intramolecular distribution of the naturally occurring ${ }^{15} \mathrm{~N}$ and ${ }^{18} \mathrm{O}$ isotopes in the linear $\mathrm{N}_{2} \mathrm{O}$ molecule and applied the $\mathrm{N}_{2} \mathrm{O}$ isotopocule mapping approach to estimate the contribution of denitrification to $\mathrm{N}_{2} \mathrm{O}$ formation $[22,23]$.

\section{Materials and Methods}

\subsection{Preparation of Soil and Plant Material}

The soil for the experiment was taken from a long-term field experiment at the grassland research station of the University of Gießen (latitude $\mathrm{N} 50^{\circ} 32^{\prime}$, longitude $\mathrm{E} 8^{\circ} 41.3^{\prime}$, elevation $172 \mathrm{~m}$ a.s.l.), sieved to $10 \mathrm{~mm}$, air-dried, and stored at $4{ }^{\circ} \mathrm{C}$. The soil was classified as Fluvic Gleysol of clay loam texture (32\% clay, $41 \%$ silt, and $27 \%$ sand) with a $\mathrm{pH}\left(\mathrm{CaCl}_{2}\right)$ of 5.67. Total soil $\mathrm{N}$ content was $0.42 \%$, total soil $\mathrm{C}$ content was $4.2 \%$, and $\delta{ }^{13} \mathrm{C}$ was $-28.37 \%$. Prior to the incubation experiment, the soil was pre-incubated in the dark for 5 weeks at $50 \%$ water holding capacity (WHC) and $20^{\circ} \mathrm{C}$.

Maize plants (Zea mays L. cv. Ronaldinio) were grown in nutrient solution [24] for 5 weeks. Leaves were cut from stems and left to wilt at room temperature for $4 \mathrm{~h}$. Roots were rinsed with $\mathrm{H}_{2} \mathrm{O}_{\text {dest }}$ and carefully dried with paper towels. Leaves and roots were stored at $4{ }^{\circ} \mathrm{C}$ and $90 \%$ relative humidity until experimental setup. Maize straw was collected from an experimental field site of the University of Göttingen after grain harvest in October 2018. Maize straw was shock frozen in liquid $\mathrm{N}_{2}$ and stored at $-20^{\circ} \mathrm{C}$. Prior to setting up the experiment, maize straw was unfrozen and all maize litter was cut to a size of $2 \mathrm{~cm}$. A subsample of soil and maize litter was analyzed for total N, total C, and $\delta$ ${ }^{13} \mathrm{C}$ using an elemental analyzer (NA1110, CE-Instruments, Rodano, Milano, Italy) linked to a gas-isotope ratio mass spectrometer (Delta Plus, Finnigan MAT, Bremen, Germany) via a Conflo III Interface (Finnigan MAT, Bremen, Germany). Further, plant litter was 
analyzed for water-extractable $\mathrm{C}$ and $\mathrm{N}$ content. Briefly, $0.2 \mathrm{~g}$ of finely ground plant litter were extracted in $100 \mathrm{~mL} \mathrm{H}_{2} \mathrm{O}_{\text {bidest}}$, shaken for $1 \mathrm{~h}$, filtered with $0.45 \mu \mathrm{m}$ polyether sulfone filters (Labsolute, Renningen, Germany), and stored at $-20^{\circ} \mathrm{C}$. The extracts were analyzed for organic $\mathrm{C}$ and total $\mathrm{N}$ content using a multi N/C $\mathrm{C}^{\circledR}$ Analyzer (Analytik Jena, Jena, Germany). Another subsample of finely ground plant litter was analyzed by ${ }^{13} \mathrm{C}$ solidstate cross polarization magic angle spinning nuclear magnetic resonance spectroscopy $\left({ }^{13} \mathrm{C}\right.$-CPMAS NMR) using a Bruker Avance ${ }^{\mathrm{III}} 200$ spectrometer (Bruker BioSpin GmbH, Karlsruhe, Germany). Samples were weighed into zircon oxide rotors and spun around a magic angle at a speed of $6.8 \mathrm{kHz}$. Contact time was $1 \mathrm{~ms}$ and the recycle delay time was set to $2 \mathrm{~s}$, line broadening was set at 0 . Peak integration areas were separated into -10-45 ppm (alkyl C), 45-110 ppm (O/N-alkyl C), 110-160 ppm (aryl C), and 160-220 ppm (carboxylic C).

\subsection{Automatized Laboratory Incubation Experiment and Gas Analysis}

The incubation experiment was carried out under fully controlled conditions using an automated soil incubation system with artificial atmosphere similar to systems described earlier [25-28]. For the incubation experiment, soil moisture was adjusted to $70 \%$ waterfilled pore space (WFPS, equivalent to $67.7 \%$ WHC or $31.9 \%$ gravimetric water content) and $50 \mathrm{mg} \mathrm{N} \mathrm{kg}^{-1}$ was added by spraying a $\mathrm{KNO}_{3}$ solution onto the soil and thoroughly stirring it with a spoon. For treatments with litter, litter was homogenously mixed with soil (Maize leaves: $40.5 \mathrm{~g} \mathrm{FM} \mathrm{kg}^{-1}$, maize roots: $42 \mathrm{~g} \mathrm{FM} \mathrm{kg}^{-1}$, maize straw: $12.8 \mathrm{~g} \mathrm{FM} \mathrm{kg}^{-1}$ ). The soil for each pot was prepared separately to ensure the same amount of litter was added. Then, the equivalent of $2.5 \mathrm{~kg}$ dry soil was filled into acrylic glass pots (inner diameter $172 \mathrm{~mm}$, height $210 \mathrm{~mm}$ ) with a porous ceramic plate at the bottom and compacted in a stepwise mode by filling a $2 \mathrm{~cm}$-layer of soil in pots and compacting it with a plunger. To ensure continuity between soil layers, the surface of the compacted layer was gently scratched before adding the next soil layer. Soil height in the pots was $10 \mathrm{~cm}$, and bulk density was $1.1 \mathrm{~g} \mathrm{~cm}^{-3}$. Each litter treatment was replicated five times, a control treatment without litter was replicated four times, and one empty pot was included as reference to determine background gas concentrations.

Pots were tightly closed with transparent acrylic glass lids with rubber seals, and the outside of the pots was covered with dark plastic sheets to prevent algae growth. Pots were alternately evacuated using a rotary vacuum pump (Pfeiffer Vacuum $\mathrm{GmbH}$, Asslar, Germany) and flushed with a gas mixture $\left(80 \% \mathrm{He}, 20 \% \mathrm{O}_{2}\right)$ for $24 \mathrm{~h}$. The gas mixture was prepared by using stainless steel capillaries of different length and inner diameter. For the first cycles, pots were evacuated from the top and the bottom and, subsequently, flushed with the $\mathrm{He} / \mathrm{O}_{2}$ gas mixture. Then, pots were evacuated from the bottom and simultaneously flushed from the top to replace the atmosphere inside the soil column. For measurements, the outlet of all pots was connected to flow-through multiposition valves (16 ports, Vici Valco Instruments, Houston, TX, USA) with multi-position actuator control modules (Vici Valco Instruments, Houston, TX, USA), and controlled by Trilution Software (Gilson Inc., Middleton, WI, USA) via an interface module (506C System Interface, Gilson Inc., Middleton, WI, USA). The selected stream outlet tube of the multi-position valve was connected to a gas chromatograph (GC-450, Bruker, Billerica, USA) equipped with a thermal conductivity detector (TCD) for measurement of $\mathrm{CO}_{2}$ and a pulsed discharge detector (PDD, Vici AG International, Schenkon, Switzerland) for $\mathrm{N}_{2} \mathrm{O}$ and $\mathrm{N}_{2}$. The sample gas outlet of the GC was connected to a flow-through massflowmeter (Alicat Scientific, Tucson, AZ, USA), and a trace-level gas analyzer (CLD 88Yp, Eco Physics AG, Dürnten, Switzerland) equipped with a chemoluminescence detector (CLD) to analyze NO concentrations. To add up to the required 300-mL-flow of the NO analyzer, samples were diluted with synthetic air. Processing of GC data was done using CompassCDS software (SCION Instruments, Livingston, UK). Data from the NO analyzer and flowmeter were read out every $10 \mathrm{~s}$ via a serial port. 
The analytical precision of the GC was determined by repeated measurements of standard gases $\left(\mathrm{CO}_{2}, \mathrm{~N}_{2} \mathrm{O}, \mathrm{N}_{2}\right)$ and was consistently $<2 \%$. Detection limits were $0.08 \mu \mathrm{g}$ $\mathrm{N}_{2} \mathrm{O}-\mathrm{N} \mathrm{kg}^{-1} \mathrm{~h}^{-1}$ and $5.5 \mu \mathrm{g} \mathrm{N}_{2}-\mathrm{N} \mathrm{kg}^{-1} \mathrm{~h}^{-1}$. The non-selected outlet streams of the multiposition valves were used to sample headspace gas for analysis of isotopic compositions ( $\delta$ ${ }^{13} \mathrm{C}_{\text {of }} \mathrm{CO}_{2}$, isotopocules of $\mathrm{N}_{2} \mathrm{O}$ ). After 47 days, the pots were flushed with pure helium to establish anoxic conditions to determine potential denitrification. After 8 days of anoxic incubation (55 days in total), the pots were opened for final sampling.

\section{3. ${ }^{13} \mathrm{CO}_{2}$ Sampling, Analysis, and Calculations}

For determination of $\delta^{13} \mathrm{C}$ of soil-emitted $\mathrm{CO}_{2}$, samples were flushed into $12 \mathrm{~mL}$ Exetainer $^{\circledR}$ septum-capped vials (Labco, High Wycombe, UK). Samples were taken twice a day for the first 5 days, daily for the next 12 days, every second day for the next 14 days, and every 3 days until day 43. Samples were introduced by a Combi-Pal autosampler (CTC-Analytics, Zwingen, Switzerland) to a GC (GC-Box, Thermo Fisher Scientific, Bremen, Germany) coupled to an isotope ratio mass spectrometer (Delta plus XP, Thermo Fisher Scientific, Bremen, Germany) via a Conflo III Interface (Thermo Fisher Scientific, Bremen, Germany). The fractions of $\mathrm{CO}_{2}$ derived from litter $\left(\mathrm{f}_{\text {litter }}\right)$ and SOM $\left(\mathrm{f}_{\mathrm{SOM}}\right)$ were calculated using Equations (1) and (2):

$$
\begin{gathered}
\mathrm{f}_{\text {litter }}=\left(\delta^{13} \mathrm{C}_{\text {treatment }}-\delta^{13} \mathrm{C}_{\text {Control }}\right) /\left(\delta^{13} \mathrm{C}_{\text {litter }}-\delta^{13} \mathrm{C}_{\text {Control }}\right) \\
\mathrm{f}_{\text {litter }}+\mathrm{f}_{\mathrm{SOM}}=1
\end{gathered}
$$

where $\delta^{13} \mathrm{C}_{\text {treatment }}$ is the measured $\delta^{13} \mathrm{C}(\%)$ of $\mathrm{CO}_{2}$ from litter treatment, $\delta^{13} \mathrm{C}_{\text {Control }}$ is the measured $\delta^{13} \mathrm{C}(\%)$ of $\mathrm{CO}_{2}$ from control treatment without litter addition, and $\delta^{13} \mathrm{C}_{\text {litter }}$ is the mean measured $\delta^{13} \mathrm{C}(\%)$ of $\mathrm{CO}_{2}$ lost from maize litter (Leaf: $-7.91 \delta \%$, Root: $-7.50 \delta \%$, Straw: $-9.33 \delta \%$, see supplement for details, Figure S2). For each treatment, the priming effect $(P E)$ was calculated as the difference between SOM-derived $\mathrm{CO}_{2}-\mathrm{C}$ $\left(\mathrm{C}_{\mathrm{SOM}}\right)$ and $\mathrm{CO}_{2}-\mathrm{C}$ from control treatment without litter $\left(\mathrm{C}_{\mathrm{Control}}\right)(3)$ :

$$
\mathrm{PE}=\mathrm{C}_{\mathrm{SOM}}-\mathrm{C}_{\mathrm{Control}}
$$

\section{4. ${ }^{15} \mathrm{~N}_{2} \mathrm{O}$ Sampling, Analysis, and Isotopocule Mapping Approach}

On 2, 5, 8, 15, 23, 31, 39, 48, 51, and 54 days after onset of incubation (DAO), samples for analyses of $\mathrm{N}_{2} \mathrm{O}$ isotopomers were flushed into $100 \mathrm{~mL}$ crimp-top vials with butyl rubber septa. Samples were analyzed on a gas-isotope ratio mass spectrometer (Delta plus XP, Finnigan MAT, Bremen, Germany) coupled to a trace gas pre-concentration unit Precon (Thermo Electron Cooperation, Bremen, Germany) via a GC/GP Interface (Thermo Electron Cooperation, Bremen, Germany). In this setup, $m / z 44,45$, and 46 of the intact $\mathrm{N}_{2} \mathrm{O}^{+}$molecular ions and $m / z 30$ and 31 of the $\mathrm{NO}^{+}$fragment ions are measured simultaneously [29], and $\delta^{15} \mathrm{~N}^{\text {bulk }}{ }_{\mathrm{N} 2 \mathrm{O}}, \delta^{15} \mathrm{~N}^{\alpha}{ }_{\mathrm{N} 2 \mathrm{O}}$, and $\delta^{18} \mathrm{O}_{\mathrm{N} 2 \mathrm{O}}$ values were determined [30]. $\delta^{15} \mathrm{~N}^{\beta} \mathrm{N} 2 \mathrm{O}$ values were calculated based on the following Equation (4):

$$
\delta^{15} \mathrm{~N}^{\text {bulk }}{ }_{\mathrm{N} 2 \mathrm{O}}=\left(\delta^{15} \mathrm{~N}^{\alpha}{ }_{\mathrm{N} 2 \mathrm{O}}+\delta^{15} \mathrm{~N}^{\beta}{ }_{\mathrm{N} 2 \mathrm{O}}\right) / 2
$$

Site preference $\left(\delta^{15} \mathrm{~N}^{\mathrm{SP}}{ }_{\mathrm{N} 2 \mathrm{O}}\right)$ was calculated as the difference between $\delta^{15} \mathrm{~N}^{\alpha}{ }_{\mathrm{N} 2 \mathrm{O}}$ and $\delta^{15} \mathrm{~N}^{\beta} \mathrm{N} 2 \mathrm{O}$. We used the scrambling factor of 0.096 determined by Buchen et al. (2018) [31] to correct measured data [32]. $\delta^{18} \mathrm{O}$ of soil water was $-6.7 \delta \%$.

We applied the isotopocule mapping approach by Lewicka-Szczebak et al. (2017) [22] to calculate the fraction of residual unreduced $\mathrm{N}_{2} \mathrm{O}\left(\mathrm{rN}_{2} \mathrm{O}\right)$ and the $\mathrm{N}_{2} \mathrm{O}$ fraction from heterotrophic bacterial denitrification $\left(\mathrm{f}_{\mathrm{bD}}\right)$ based on the sample position in the $\delta^{15} \mathrm{~N}^{\mathrm{SP}} / \delta^{18} \mathrm{O}$ map using a mixing equation for the bacterial fraction (6) and the Rayleigh equation for $\mathrm{N}_{2} \mathrm{O}$ reduction (5):

$$
\begin{gathered}
\mathrm{r}_{\mathrm{N} 2 \mathrm{O}}=\mathrm{e}^{((\delta \mathrm{r}-\delta 0) / \eta \mathrm{red})} \\
\delta_{0 \_ \text {sample }}=\delta_{\mathrm{bD}} * \mathrm{f}_{\mathrm{bD}}+\delta_{\mathrm{fD} / \mathrm{Ni}} *\left(1-\mathrm{f}_{\mathrm{bD}}\right)
\end{gathered}
$$


where $\delta_{\mathrm{r}}$ is the isotopic signature of residual $\mathrm{N}_{2} \mathrm{O}$ after partial reduction, $\delta_{0}$ is the isotopic signature of initial $\mathrm{N}_{2} \mathrm{O}$ before reduction, and $\eta_{\text {red }}$ is the isotopic fractionation factor associated with $\mathrm{N}_{2} \mathrm{O}$ reduction to $\mathrm{N}_{2}$. Two main scenarios were considered: (1) $\mathrm{N}_{2} \mathrm{O}$ emitted from bacterial denitrification is first reduced to $\mathrm{N}_{2}$ and residual $\mathrm{N}_{2} \mathrm{O}$ is then mixed with $\mathrm{N}_{2} \mathrm{O}$ originating from nitrification or fungal denitrification (Scenario 1, reduction-mixing). Alternatively, (2) $\mathrm{N}_{2} \mathrm{O}$ from bacterial denitrification and nitrification or fungal denitrification is first mixed and then partially reduced to $\mathrm{N}_{2}$ (Scenario 2, mixing-reduction). Recently, non-overlapping signatures for $\mathrm{N}_{2} \mathrm{O}$ produced by nitrification or fungal denitrification were proposed [23], and we calculated both scenarios for mixing of bacterial denitrification with either nitrification or fungal denitrification. A detailed description of the calculations can be found in [33]. We used the isotopic fractionation factors proposed by [23] (Supplementary Table S1), which were corrected for $\delta^{18} \mathrm{O}$ of soil water $(-6.7 \delta \%$ ) for mapping and calculations.

In addition, calculations can be based on minimum or maximum end-member values, fractionation factors, and reduction factors, leading to a total of 14 different scenarios [31]. In our study, we used mean values for mixing, fractionation, and reduction whenever possible. However, as during anoxic incubation, samples were distributed outside the mean mixing-reduction area, we used minimum reduction values (mean mixing, mean fractionation) for 51 and $54 \mathrm{DAO}$. When calculations yielded values $<0$ or $>1 \mathrm{for} \mathrm{fbD}$ or $\mathrm{rN}_{2} \mathrm{O}$, these values were removed from the dataset before calculating means and plotting.

\subsection{Soil Analyses}

Samples of pre-incubated soil were taken prior to experimental setup. After opening pots at the end of the experiment, soil from each pot was homogenized and a sample was taken for analyses. Subsamples were analyzed for soil mineral N, water-extractable organic

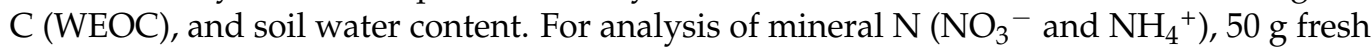
soil were weighed into plastic bottles and frozen at $-20{ }^{\circ} \mathrm{C}$ until analysis. Frozen samples were extracted with $2 \mathrm{M} \mathrm{KCl}$ solution (1:5 w:v) and shaken on an overhead shaker for $60 \mathrm{~min}$. Samples were filtered with $615 \frac{1}{4}$ filter paper (Macherey-Nagel GmbH \& Co. KG, Düren, Germany) and extracts were analyzed colorimetrically using the San ${ }^{++}$ContinuousFlow Analyzer (Skalar Analytical B.V., Breda, The Netherlands). To determine isotopic signatures of nitrate, the bacterial denitrification method with Pseudomonas aureofaciens was applied [34,35].

WEOC was extracted by homogenizing $2 \mathrm{~g}$ of fresh soil with $10 \mathrm{~mL} \mathrm{H}_{2} \mathrm{O}_{\text {bidest. Samples }}$ were centrifuged, filtered with $0.45 \mu \mathrm{m}$ polyether sulfone filters (Labsolute, Renningen, Germany), and stored at $-20^{\circ} \mathrm{C}$. The extracts were analyzed for organic $\mathrm{C}$ and total $\mathrm{N}$ content using a multi N/C $\mathrm{C}^{\circledR}$ Analyzer (Analytik Jena, Jena, Germany). Soil water content was determined by oven drying at $105^{\circ} \mathrm{C}$.

\subsection{Calculations and Statistics}

For all calculations and statistical analyses, the statistical software $\mathrm{R}$ version 3.6.0 [36] was used. Fluxes of $\mathrm{CO}_{2}, \mathrm{~N}_{2} \mathrm{O}, \mathrm{N}_{2}$, and $\mathrm{NO}\left(\mathrm{F}, \mu \mathrm{g} \mathrm{kg}{ }^{-1} \mathrm{~h}^{-1}\right)$ were calculated using the dynamic chamber approach (7):

$$
\mathrm{F}=\left(\mathrm{C}_{\mathrm{o}}-\mathrm{C}_{\mathrm{i}}\right) * \mathrm{Q} / \mathrm{m}
$$

where $C_{o}$ is the concentration at the outflow and $C_{i}$ is the concentration at the inflow of each vessel ( $\mathrm{mg} \mathrm{N} \mathrm{m}^{-3}$, or $\left.\mathrm{mg} \mathrm{C} \mathrm{m}^{-3}\right), Q$ is the flow rate through the headspace $\left(\mathrm{m}^{3} \mathrm{~h}^{-1}\right)$, and $m$ is the dry mass of soil per vessel $(\mathrm{kg})$.

Net N mineralization was calculated according to Equation (8):

Net $\mathrm{N}$ mineralization $=\mathrm{NO}_{3}{ }^{-}$end $+\mathrm{NH}_{4}{ }^{+}$end $+\mathrm{NO}_{\mathrm{cml}}+\mathrm{N}_{2} \mathrm{O}_{\mathrm{cml}}+\mathrm{N}_{2 \mathrm{cml}}-\left(\mathrm{NO}_{3}{ }^{-}\right.$start $+\mathrm{NH}_{4}{ }^{+}$start $+\mathrm{NO}_{3}{ }^{-}$fertilizer $)$

Mean values and standard deviations were calculated using the SlidingWindow function from the package evobiR v.1.1 [37] or the rollapply function from the package zoo [38]. 
Cumulative emissions were calculated by interpolation between measured fluxes. To test for differences between treatments, a one-way ANOVA was calculated when data were normally distributed or the Kruskal-Wallis rank sum test for non-normally distributed data followed by the LSD post hoc test. A $t$-test at $p<0.05$ was used to compare soil $\mathrm{NO}_{3}{ }^{-}$, $\mathrm{NH}_{4}{ }^{+}$, and WEOC content before and after the incubation. To analyze the effect of litter input and litter quality on $\mathrm{CO}_{2}$ and $\mathrm{N}$ emissions, simple linear regression models were tested. In all plots, color schemes from the R package viridisLite v0.3.0 [39] were used.

\section{Results}

\subsection{Characterization of Maize Litter}

Maize litter types differed in their chemical composition (Table 1). Total C content ranged between $40 \%$ in maize roots and $47 \%$ in maize leaves. Total $\mathrm{N}$ content ranged between $3.8 \%$ in maize leaves and $0.85 \%$ in maize straw. C: $\mathrm{N}$ ratio was highest in maize straw (51.4) and similar in maize leaves and roots (12.3 and 13.8, respectively). Watersoluble $\mathrm{C}$ contents were similar in all maize litter types (8-8.5\%). Water-soluble $\mathrm{N}$ content was highest in maize roots $(1.22 \%)$ and lowest in maize straw $(0.39 \%)$. Thus, water-soluble $\mathrm{C}: \mathrm{N}$ was highest in maize straw and lowest in maize roots. ${ }^{13} \mathrm{C}-\mathrm{CPMAS} N M R$ spectroscopy of maize litter revealed that maize straw and maize leaves were closer in their chemical composition than maize roots (Table 1, spectra in Supplementary Figure S1). Maize roots were characterized by the lowest shares of alkyl $\mathrm{C}$ and carboxyl $\mathrm{C}$ and the highest share of $\mathrm{O} / \mathrm{N}-a l k y l \mathrm{C}$, while maize leaves had highest shares of carboxyl $\mathrm{C}$ and alkyl $\mathrm{C}$.

\subsection{Soil $N$ and $C$ Content}

Soil $\mathrm{NO}_{3}{ }^{-}$content increased in Control, Leaf, and Root treatments during the incubation experiment due to a net mineralization of $\mathrm{N}$ (Table 2). In contrast, addition of maize straw significantly decreased soil $\mathrm{NO}_{3}{ }^{-}$content and immobilized N. Soil $\mathrm{NH}_{4}{ }^{+}$content strongly decreased in all treatments during the incubation period and was significantly higher in all maize litter treatments than in Control, but differences between treatments were small. WEOC content increased in all maize litter treatments, but did not change in Control. No differences were found in soil WEOC content between different litter treatments at the end of the experiment.

$\delta^{15} \mathrm{~N}_{\mathrm{NO} 3}$ and $\delta^{18} \mathrm{O}_{\mathrm{NO} 3}$ of added $\mathrm{KNO}_{3}$ were higher compared to initial soil $\mathrm{NO}_{3}{ }^{-}$ at onset of incubation (Table 2). At the end of the incubation experiment, $\delta^{15} \mathrm{~N}_{\mathrm{NO}}$ and $\delta^{18} \mathrm{O}_{\mathrm{NO} 3}$ of soil $\mathrm{NO}_{3}{ }^{-}$differed between litter treatments. The lowest $\delta^{15} \mathrm{~N}_{\mathrm{NO} 3}$ was measured in Root, and the lowest $\delta^{18} \mathrm{O}_{\mathrm{NO} 3}$ in Control and Leaf. The highest $\delta^{15} \mathrm{~N}_{\mathrm{NO}}$ and $\delta^{18} \mathrm{O}_{\mathrm{NO} 3}$ were measured in Straw. $\delta^{15} \mathrm{~N}_{\mathrm{NO} 3}$ increased with decreasing net $\mathrm{N}$ mineralization (adj. $R^{2}=0.73, p<0.001$, Table 3). 


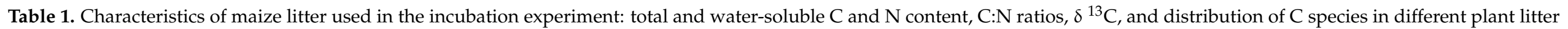
types (values represent the percentage contribution of the different integrated chemical shift regions determined by ${ }^{13} \mathrm{C}-\mathrm{CPMAS}$ NMR spectroscopy).

\begin{tabular}{|c|c|c|c|c|c|c|c|c|c|c|c|c|}
\hline & $\begin{array}{l}\text { Dry Matter } \\
(\%)\end{array}$ & $\begin{array}{c}\mathrm{C} \\
(\%)\end{array}$ & $\begin{array}{c}\delta^{13} \mathrm{C} \\
(\% \circ)\end{array}$ & $\begin{array}{c}N \\
(\%)\end{array}$ & $\mathrm{C}: \mathrm{N}$ & $\begin{array}{c}\text { Water Soluble C } \\
(\%)\end{array}$ & $\begin{array}{c}\text { Water Soluble N } \\
(\%)\end{array}$ & $\begin{array}{c}\text { Water Soluble } \\
\text { C:N }\end{array}$ & $\begin{array}{c}\text { Alkyl C } \\
(\%)\end{array}$ & $\begin{array}{c}\text { O/N-Alkyl C } \\
(\%)\end{array}$ & $\begin{array}{c}\text { Aryl C } \\
(\%)\end{array}$ & $\begin{array}{c}\text { Carboxyl C } \\
(\%)\end{array}$ \\
\hline Maize leaves & 27.9 & 46.58 & -14.70 & 3.80 & 12.27 & 8.03 & 0.69 & 11.6 & 16.05 & 63.67 & 10.96 & 9.31 \\
\hline Maize roots & 7.8 & 40.12 & -12.97 & 2.90 & 13.82 & 8.53 & 1.22 & 7.0 & 8.08 & 80.65 & 10.19 & 1.10 \\
\hline
\end{tabular}

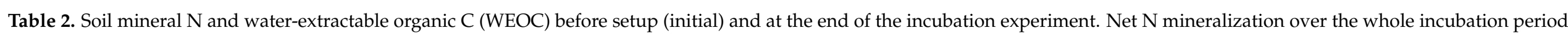
of 55 days.

\begin{tabular}{|c|c|c|c|c|c|c|c|c|c|c|c|c|}
\hline & \multicolumn{2}{|c|}{$\begin{array}{c}\mathrm{NO}_{3}^{-} \\
\text {(mg N kg }{ }^{-1} \text { dry soil) }\end{array}$} & \multicolumn{2}{|c|}{$\begin{array}{c}\mathrm{NH}_{4}^{+} \\
\text {(mg N kg } \\
-1 \text { dry soil) }\end{array}$} & \multicolumn{2}{|c|}{$\begin{array}{c}\text { WEOC } \\
\text { (mg C kg } \text { kg }^{-1} \text { dry soil) }\end{array}$} & \multicolumn{2}{|c|}{$\begin{array}{l}\text { Net } N \text { Mineralization } \\
\text { (mg N kg }{ }^{-1} \text { dry soil) }\end{array}$} & \multicolumn{2}{|c|}{$\begin{array}{c}\delta^{15} \mathrm{~N}_{\mathrm{NO} 3} \text { of Soil } \mathrm{NO}_{3}{ }^{-} \\
(\%)\end{array}$} & \multicolumn{2}{|c|}{$\begin{array}{c}\delta^{18} \mathrm{O}_{\mathrm{NO} 3} \text { of Soil } \mathrm{NO}_{3}^{-} \\
(\%)\end{array}$} \\
\hline Initial & \multicolumn{2}{|c|}{$102.9 \pm 4.59$} & \multicolumn{2}{|c|}{$34.7 \pm 3.16$} & \multicolumn{2}{|c|}{$51.4 \pm 6.49$} & \multicolumn{2}{|c|}{ - } & \multicolumn{2}{|c|}{$-5.74 \pm 0.19 / 2.44 \pm 0.22^{1}$} & \multicolumn{2}{|c|}{$1.84 \pm 0.29 / 22.95 \pm 0.40$} \\
\hline Control & $142.1 \pm 7.8$ & $b^{* * *}$ & $4.12 \pm 0.27$ & $c^{* * *}$ & $56.3 \pm 8.0$ & $\mathrm{~b}$ & $26.4 \pm 5.5$ & $\mathrm{~b}$ & $7.80 \pm 0.58$ & $\mathrm{bc}$ & $9.21 \pm 1.05$ & c \\
\hline Maize Roots & $176.1 \pm 6.9$ & $a^{* * *}$ & $4.85 \pm 0.39$ & $b^{* * *}$ & $72.0 \pm 5.7$ & $a * * *$ & $69.3 \pm 5.4$ & $\mathrm{a}$ & $6.64 \pm 0.62$ & c & $11.49 \pm 0.52$ & $\mathrm{~b}$ \\
\hline Maize Straw & $70.6 \pm 5.6$ & $c^{* * *}$ & $6.00 \pm 0.60$ & $a^{* * *}$ & $71.9 \pm 5.3$ & $a^{* * *}$ & $-26.8 \pm 5.7$ & c & $16.40 \pm 1.63$ & a & $14.53 \pm 0.34$ & a \\
\hline
\end{tabular}

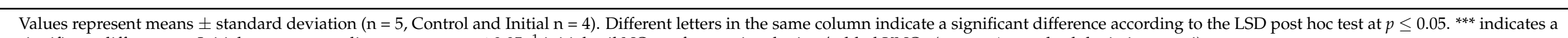
significant difference to Initial content according to $t$-test at $p \leq 0.05 .{ }^{1}$ initial soil $\mathrm{NO}_{3}{ }^{-}$after pre-incubation $/$added $\mathrm{KNO}_{3}($ means \pm standard deviation, $\mathrm{n}=4$ ). 
Table 3. Coefficients of determination and $p$-values for simple linear regressions.

\begin{tabular}{|c|c|c|c|}
\hline & Adjusted $\mathrm{R}^{2}$ & $p$-Value & $\mathbf{n}$ \\
\hline \multicolumn{4}{|l|}{ Oxic incubation period } \\
\hline Cumulative $\mathrm{NO}+\mathrm{N}_{2} \mathrm{O}$ emissions $\sim$ water-soluble litter $\mathrm{C}$ input & 0.4401 & 0.001172 & 19 \\
\hline Cumulative $\mathrm{N}_{2} \mathrm{O}$ emissions $\sim$ litter $\mathrm{C}: \mathrm{N}$ ratio & 0.247 & 0.03428 & 15 \\
\hline Cumulative NO emissions $\sim$ water-soluble litter C:N ratio & 0.8703 & $2.427 \times 10^{-7}$ & 15 \\
\hline Cumulative $\mathrm{NO}$ emission $\sim$ net $\mathrm{N}$ mineralization & 0.5671 & 0.0001197 & 19 \\
\hline $\mathrm{NO}+\mathrm{N}_{2} \mathrm{O}$ flux $\sim \mathrm{CO}_{2}$ flux & 0.08023 & $<2.2 \times 10^{-16}$ & 1715 \\
\hline \multicolumn{4}{|l|}{ Anoxic incubation period } \\
\hline Cumulative $\mathrm{N}_{2}$ emissions $\sim$ water-soluble litter $\mathrm{C}: \mathrm{N}$ ratio & 0.2553 & 0.03158 & 15 \\
\hline Cumulative $\mathrm{NO}+\mathrm{N}_{2} \mathrm{O}+\mathrm{N}_{2}$ emissions $\sim$ total litter $\mathrm{C}$ input & 0.5087 & 0.0003655 & 19 \\
\hline $\mathrm{N}_{2} \mathrm{O} /\left(\mathrm{N}_{2} \mathrm{O}+\mathrm{N}_{2}\right)$ ratio $\sim$ water-soluble litter $\mathrm{C}: \mathrm{N}$ ratio & 0.5061 & $1.886 \times 10^{-6}$ & 19 \\
\hline $\mathrm{N}_{2} \mathrm{O} /\left(\mathrm{N}_{2} \mathrm{O}+\mathrm{N}_{2}\right)$ ratio $\sim$ WEOC: $\mathrm{NO}_{3}{ }^{-}$ratio & 0.4127 & 0.0018 & 19 \\
\hline $\mathrm{NO}+\mathrm{N}_{2} \mathrm{O}+\mathrm{N}_{2}$ flux $\sim \mathrm{CO}_{2}$ flux & 0.864 & $<2.2 \times 10^{-16}$ & 176 \\
\hline \multicolumn{4}{|l|}{ Total incubation period } \\
\hline Cumulative $\mathrm{CO}_{2}$ emissions $\sim$ total litter $\mathrm{C}$ input & 0.8974 & $4.84 \times 10^{-10}$ & 19 \\
\hline Cumulative $\mathrm{CO}_{2}$ emissions $\sim$ water-soluble litter $\mathrm{C}$ input & 0.798 & $1.606 \times 10^{-7}$ & 19 \\
\hline Litter-derived $\mathrm{CO}_{2}$ flux $\sim \mathrm{SOM}$-derived $\mathrm{CO}_{2}$ flux & 0.8838 & $<2.2 \times 10^{-16}$ & 495 \\
\hline$\delta^{15} \mathrm{~N}_{\mathrm{NO} 3}$ of soil $\mathrm{NO}_{3}{ }^{-} \sim$ net $\mathrm{N}$ mineralization (52 DAO) & 0.729 & $<2.024 \times 10^{-6}$ & 19 \\
\hline
\end{tabular}

\section{3. $\mathrm{CO}_{2}$ and ${ }^{13} \mathrm{CO}_{2}$ Fluxes and Cumulative Emissions}

$\mathrm{CO}_{2}$ fluxes from all litter treatments increased after onset of incubation compared to Control (Figure $1 \mathrm{a}, \mathrm{b}$, Supplementary Figure S3). Total $\mathrm{CO}_{2}$ fluxes were highest in Leaf reaching $5.1 \mathrm{mg} \mathrm{C} \mathrm{kg}^{-1} \mathrm{~h}^{-1}$ on $2 \mathrm{DAO}$. In Root, $\mathrm{CO}_{2}$ flux peaked on $2 \mathrm{DAO}\left(2.57 \mathrm{mg} \mathrm{C} \mathrm{kg}^{-1} \mathrm{~h}^{-1}\right)$ and then decreased throughout the incubation period. In Straw, the highest $\mathrm{CO}_{2}$ fluxes were measured directly after onset of incubation $\left(2.8 \mathrm{mg} \mathrm{C} \mathrm{kg}^{-1} \mathrm{~h}^{-1}\right)$, and continuously decreased afterwards. Litter-derived and SOM-derived $\mathrm{CO}_{2}$ followed a similar pattern as total $\mathrm{CO}_{2}$ fluxes and were highly correlated (adj. $\mathrm{R}^{2}=0.88, p<0.001$, Table 3). Highest litter-derived $\mathrm{CO}_{2}$ fluxes were measured in Leaf on $3 \mathrm{DAO}\left(3.0 \mathrm{mg} \mathrm{C} \mathrm{kg}^{-1} \mathrm{~h}^{-1}\right)$, in Straw on $1 \mathrm{DAO}\left(1.2 \mathrm{mg} \mathrm{C} \mathrm{kg}^{-1} \mathrm{~h}^{-1}\right)$, and in Root on $2 \mathrm{DAO}\left(1.7 \mathrm{mg} \mathrm{C} \mathrm{kg}^{-1} \mathrm{~h}^{-1}\right.$ ) (Figure 1a). SOM-derived $\mathrm{CO}_{2}$ was highest in Leaf and higher in all litter treatments compared to Control for the first week after onset of incubation (Figure 1b). Accordingly, the cumulative priming effect increased most strongly in all litter treatments during the first days of incubation (Figure 1c) with highest values in Leaf.

Cumulative $\mathrm{CO}_{2}$ emissions from all litter treatments were significantly higher than from Control without litter $(p<0.05$, Table 4$)$. The highest cumulative and litter-derived $\mathrm{CO}_{2}$ emissions were measured after addition of maize leaves, followed by maize straw and maize roots; however, cumulative $\mathrm{SOM}$-derived $\mathrm{CO}_{2}$ emissions were higher than litterderived $\mathrm{CO}_{2}$ emissions in all treatments (Table 4). Total cumulative $\mathrm{CO}_{2}$ emissions were significantly positively correlated with total $\mathrm{C}$ and water-soluble $\mathrm{C}$ input from maize litter (adj. $R^{2}=0.80$ and adj. $R^{2}=0.90$, respectively, $p<0.001$, Table 3 ). When total cumulative $\mathrm{CO}_{2}$ emissions were standardized against $\mathrm{C}$ input from litter, no differences were found (Supplementary Table S2). 

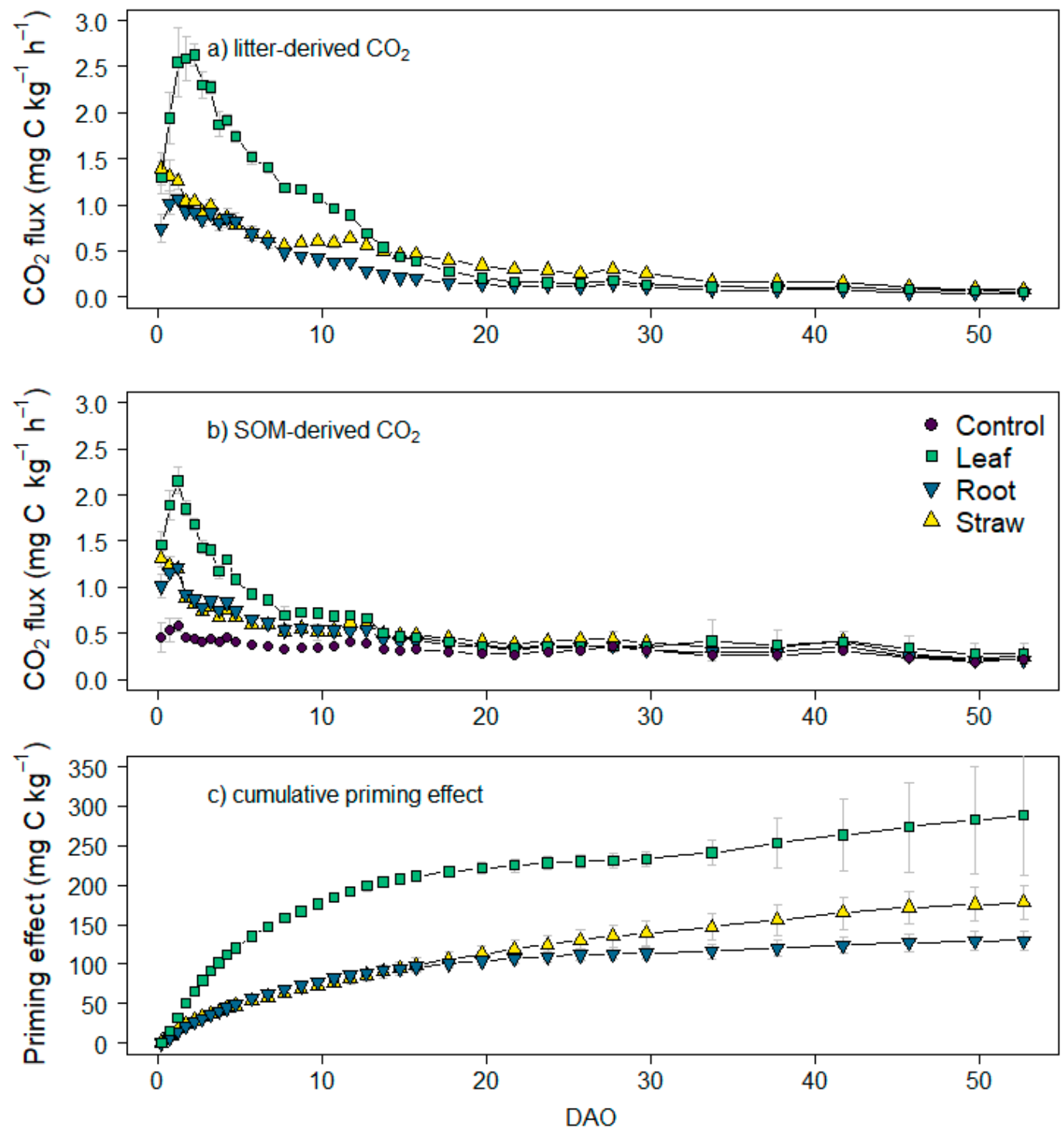

Figure 1. (a) Litter-derived $\mathrm{CO}_{2}$ fluxes, (b) SOM-derived $\mathrm{CO}_{2}$ fluxes, and (c) cumulative priming effect (means and standard deviation for $n=5, n=4$ for Control, when not visible, error bars are smaller than the symbols).

Table 4. Cumulative $\mathrm{SOM}$ and litter-derived $\mathrm{CO}_{2}$ emissions, and priming effect.

\begin{tabular}{|c|c|c|c|c|c|c|c|c|}
\hline \multirow[b]{2}{*}{ Control } & \multicolumn{2}{|c|}{$\begin{array}{c}\text { Total } \mathrm{CO}_{2} \\
\text { (mg C } \text { kg }^{-1} \text { dry soil) }\end{array}$} & \multicolumn{2}{|c|}{$\begin{array}{l}\text { SOM-Derived } \mathrm{CO}_{2} \\
\left(\mathrm{mg} \mathrm{C} \mathrm{kg}^{-1} \text { dry soil) }\right.\end{array}$} & \multicolumn{2}{|c|}{$\begin{array}{c}\text { Litter-Derived } \mathrm{CO}_{2} \\
\text { (mg C } \text { kg }^{-1} \text { dry soil) }\end{array}$} & \multicolumn{2}{|c|}{$\begin{array}{c}\text { Priming Effect } \\
\text { (mg C kg-1 dry soil) }\end{array}$} \\
\hline & $359.5 \pm 13.2$ & $\mathrm{~d}$ & $359.5 \pm 13.2$ & c & - & & - & \\
\hline Maize Leaves & $1266.0 \pm 118.8$ & a & $654.8 \pm 83.5$ & a & $597.5 \pm 33.9$ & a & $288.2 \pm 76.2$ & a \\
\hline Maize Roots & $749.8 \pm 68.1$ & c & $504.9 \pm 10.7$ & $b$ & $281.6 \pm 17.6$ & c & $130.0 \pm 12.0$ & $\mathrm{~b}$ \\
\hline Maize Straw & $970.8 \pm 34.3$ & $\mathrm{~b}$ & $561.9 \pm 26.9$ & $\mathrm{~b}$ & $449.7 \pm 21.1$ & $\mathrm{~b}$ & $178.4 \pm 21.5$ & $\mathrm{~b}$ \\
\hline
\end{tabular}

Values represent means $(n=5$, for Control $n=4) \pm$ standard deviation. Different letters in the same column indicate a significant difference.

\subsection{N Fluxes and Cumulative Emissions}

During the oxic incubation phase, only $\mathrm{N}_{2} \mathrm{O}$ and $\mathrm{NO}$ fluxes were measured as $\mathrm{N}_{2}$ fluxes were below the detection limit (Figure 2a,b). $\mathrm{N}_{2} \mathrm{O}$ fluxes from litter treatments were higher than $3.7 \mu \mathrm{g} \mathrm{N} \mathrm{kg}^{-1} \mathrm{~h}^{-1}$ for the first measurements on $1 \mathrm{DAO}$ and declined to $<1 \mu \mathrm{g} \mathrm{N} \mathrm{kg}{ }^{-1} \mathrm{~h}^{-1}$ until $5 \mathrm{DAO} . \mathrm{N}_{2} \mathrm{O}$ fluxes from litter-amended soils were in tendency higher than $\mathrm{N}_{2} \mathrm{O}$ fluxes from Control. Initial $\mathrm{NO}$ fluxes were $\sim 0.08 \mu \mathrm{g} \mathrm{N} \mathrm{kg}{ }^{-1} \mathrm{~h}^{-1}$ in Control and Root, and $\sim 0.06 \mu \mathrm{g} \mathrm{N} \mathrm{kg}{ }^{-1} \mathrm{~h}^{-1}$ in leaves and straw. In Leaf, a second NO 
peak was detected on $5 \mathrm{DAO}$. NO fluxes in Control were in tendency higher than in all litter treatments until $14 \mathrm{DAO}$, while $\mathrm{NO}$ flux declined fastest in Straw, where fluxes were smaller than in all other treatments after $3 \mathrm{DAO}$. The ratio of $\mathrm{NO} / \mathrm{N}_{2} \mathrm{O}$ was highest in Control directly after onset of incubation with maximum values of 0.47 (Supplementary Figure S5). In Root and Leaf, it reached maximum values of 0.2 and 0.1 on 5 and 6 DAO. In Straw, highest measured values were 0.1 on $2 \mathrm{DAO}$. With onset of the anoxic phase, $\mathrm{NO} / \mathrm{N}_{2} \mathrm{O}$ decreased to 0.015 in all treatments.
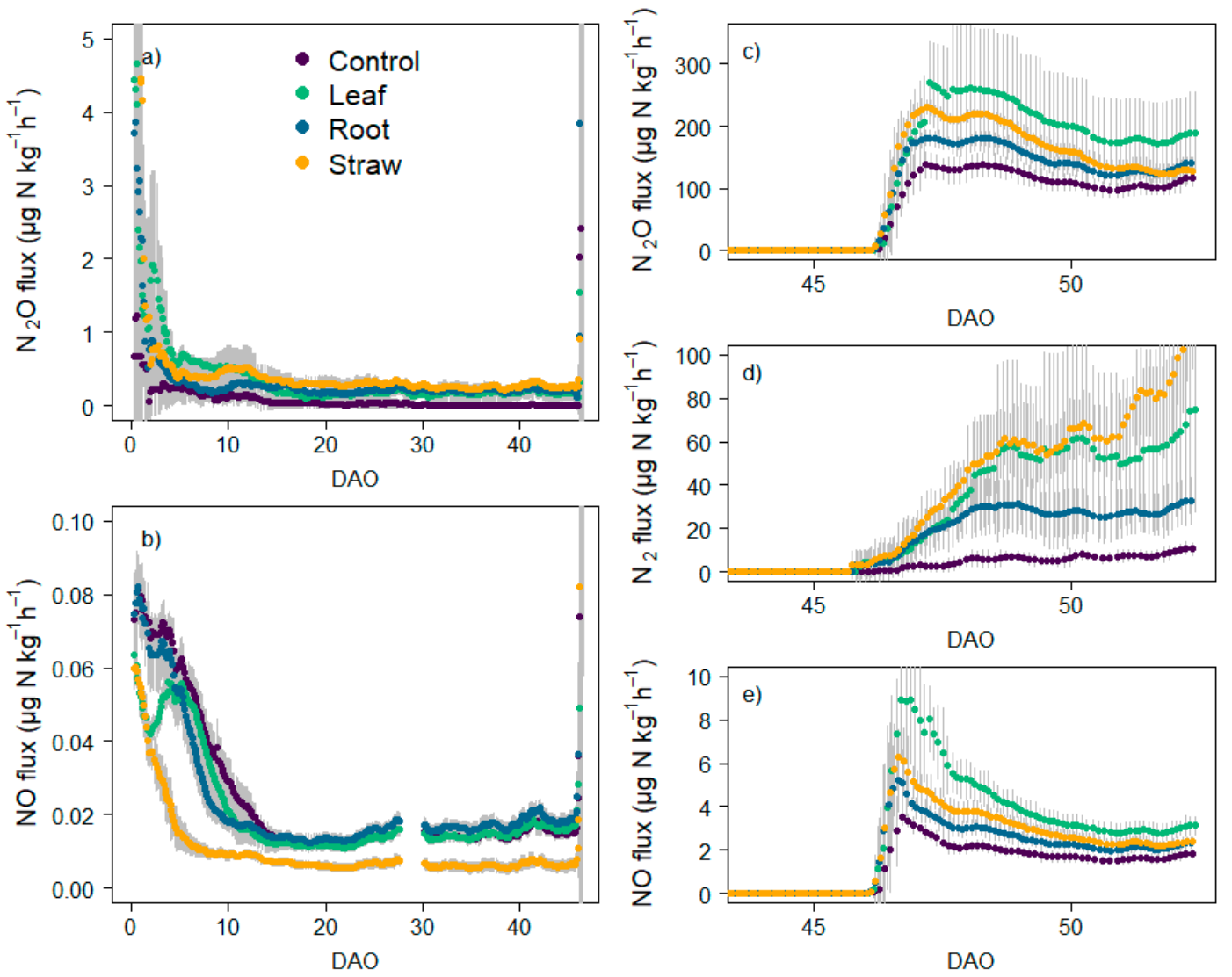

Figure 2. (a,b) $\mathrm{N}_{2} \mathrm{O}$, and $\mathrm{NO}$ fluxes during oxic incubation period (0-47 DAO). (c-e) $\mathrm{N}_{2} \mathrm{O}, \mathrm{N}_{2}$, and NO fluxes during anoxic incubation (47-55 DAO) of maize litter on grassland soil (means and standard deviation for $n=5, n=4$ for Control, when not visible, error bars are smaller than the symbols).

During the oxic phase, cumulative $\mathrm{N}_{2} \mathrm{O}$ emissions from litter-amended soil were higher than from Control $(p<0.05$, Table 5). Cumulative emissions in Straw were higher than in Root and similar to Leaf. Cumulative $\mathrm{NO}$ emissions were highest in Control and lowest in Straw, and $\mathrm{NO} / \mathrm{N}_{2} \mathrm{O}$ ratio was significantly higher in Control than in litteramended treatments. $\mathrm{NO}$ emissions strongly decreased with decreasing litter $\mathrm{C}: \mathrm{N}$ ratio (adj. $R^{2}=0.86, p<0.001$ ) and increased with increasing $\mathrm{N}$ mineralization (adj. $\mathrm{R}^{2}=0.57$, $p<0.001)$ confirming that litter quality affected nitrification-derived NO emissions during the oxic incubation phase. 
Table 5. Cumulative $\mathrm{NO}, \mathrm{N}_{2} \mathrm{O}$, and $\mathrm{N}_{2}$ emissions and ratios of gaseous products during oxic and anoxic incubation.

\begin{tabular}{|c|c|c|c|c|c|c|c|c|c|c|c|c|c|c|}
\hline \multirow[b]{3}{*}{ Control } & \multicolumn{6}{|c|}{ Oxic Incubation Phase (0-46 DAO) } & \multicolumn{8}{|c|}{ Anoxic Incubation Phase (47-55 DAO) } \\
\hline & \multicolumn{2}{|c|}{ 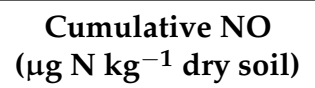 } & \multicolumn{2}{|c|}{$\begin{array}{c}\text { Cumulative } \mathrm{N}_{2} \mathrm{O} \\
\text { ( } \mu \mathrm{g} \mathrm{N} \mathrm{kg} \mathrm{kg}^{-1} \text { dry soil) }\end{array}$} & \multicolumn{2}{|c|}{$\mathrm{NO} / \mathrm{N}_{2} \mathrm{O}$} & \multicolumn{2}{|c|}{$\begin{array}{c}\text { Cumulative NO } \\
\text { (mg N kg-1 dry soil) }\end{array}$} & \multicolumn{2}{|c|}{$\begin{array}{c}\text { Cumulative } \mathrm{N}_{2} \mathrm{O} \\
\text { (mg N kg-1 dry soil) }\end{array}$} & \multicolumn{2}{|c|}{$\begin{array}{c}\text { Cumulative } \mathrm{N}_{2} \\
\text { (mg N kg-1 dry soil) }\end{array}$} & \multicolumn{2}{|c|}{$\mathrm{N}_{2} \mathrm{O} /\left(\mathrm{N}_{2} \mathrm{O}+\mathrm{N}_{2}\right)$} \\
\hline & $24.1 \pm 2.5$ & $\mathrm{a}$ & $78.3 \pm 97.2$ & $\mathrm{c}$ & $0.37 \pm 0.19$ & $\mathrm{a}$ & $0.29 \pm 0.04$ & $\mathrm{c}$ & $16.6 \pm 2.5$ & $\mathrm{c}$ & $0.88 \pm 0.33$ & c & $0.95 \pm 0.03$ & a \\
\hline Maize Leaves & $20.8 \pm 1.4$ & $\mathrm{~b}$ & $387.2 \pm 94.4$ & $\mathrm{ab}$ & $0.05 \pm 0.02$ & $\mathrm{~b}$ & $0.64 \pm 0.10$ & $\mathrm{a}$ & $29.8 \pm 9.0$ & $\mathrm{a}$ & $6.75 \pm 4.28$ & $\mathrm{ab}$ & $0.83 \pm 0.04$ & $\mathrm{~b}$ \\
\hline Maize Roots & $22.9 \pm 2.8$ & $\mathrm{ab}$ & $319.0 \pm 81.0$ & $\mathrm{~b}$ & $0.07 \pm 0.01$ & $\mathrm{~b}$ & $0.41 \pm 0.06$ & $\mathrm{~b}$ & $21.5 \pm 1.5$ & $\mathrm{bc}$ & $3.70 \pm 1.58$ & bc & $0.85 \pm 0.05$ & $\mathrm{~b}$ \\
\hline Maize Straw & $10.0 \pm 1.7$ & c & $552.2 \pm 260.7$ & $\mathrm{a}$ & $0.02 \pm 0.01$ & $\mathrm{~b}$ & $0.48 \pm 0.06$ & $\mathrm{~b}$ & $24.8 \pm 1.0$ & $\mathrm{ab}$ & $8.36 \pm 2.06$ & $\mathrm{ab}$ & $0.75 \pm 0.05$ & $\mathrm{c}$ \\
\hline
\end{tabular}

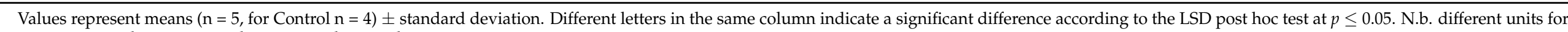
gas emissions during oxic and anoxic incubation phases. 
After 47 days, anoxic incubation conditions were induced by flushing the headspace with pure helium gas. $\mathrm{N}_{2} \mathrm{O}, \mathrm{NO}$, and $\mathrm{N}_{2}$ fluxes strongly increased with onset of anoxic incubation conditions (Figure $2 \mathrm{c}-\mathrm{e}$ ). $\mathrm{N}_{2} \mathrm{O}$ and $\mathrm{NO}$ fluxes peaked on $48 \mathrm{DAO}$ and then decreased until the end of the experiment. $\mathrm{N}_{2}$ fluxes increased after onset of anoxic conditions until the end of the experiment. During the anoxic phase, cumulative $\mathrm{N}_{2} \mathrm{O}$, $\mathrm{NO}$, and $\mathrm{N}_{2}$ emissions were higher in litter treatments than in Control, although the effect was not always statistically significant for maize roots (Table 5). The highest cumulative emissions were measured for $\mathrm{NO}\left(0.64 \mathrm{mg} \mathrm{N} \mathrm{kg}^{-1}\right)$ and $\mathrm{N}_{2} \mathrm{O}$ in Leaf $\left(29.8 \mathrm{mg} \mathrm{N} \mathrm{kg}^{-1}\right)$, and for $\mathrm{N}_{2}$ in Straw $\left(8.4 \mathrm{mg} \mathrm{N} \mathrm{kg}^{-1}\right)$. The ratio of the gaseous end products $\mathrm{N}_{2} \mathrm{O} /\left(\mathrm{N}_{2} \mathrm{O}+\mathrm{N}_{2}\right)$ was highest in Control (0.95) and lowest in Straw (0.75).

\section{5. $\mathrm{N}_{2} \mathrm{O}$ Isotopocule Mapping Approach, $f b D$ and $r \mathrm{~N}_{2} \mathrm{O}$ Values}

The $\delta^{15} \mathrm{~N}^{\mathrm{SP}} / \delta^{18} \mathrm{O}_{\mathrm{N} 2 \mathrm{O}}$ isotopocule map showed a strong influence of the incubation day on the isotopic signature of soil-emitted $\mathrm{N}_{2} \mathrm{O}$ (Figure 3). Most data points were distributed between the mixing line of bacterial and fungal denitrification and the $\mathrm{N}_{2} \mathrm{O}$ reduction line during the oxic incubation phase (0-47 DAO). With onset of anoxic incubation conditions, bacterial denitrification became the dominant process as samples measured on 48 DAO cluster tightly above the reported ranges for heterotrophic bacterial denitrification. With ongoing anoxic incubation, the samples cluster along the reduction line indicating increasing $\mathrm{N}_{2} \mathrm{O}$ reduction with ongoing anoxic incubation conditions (51 and $54 \mathrm{DAO}$ ).

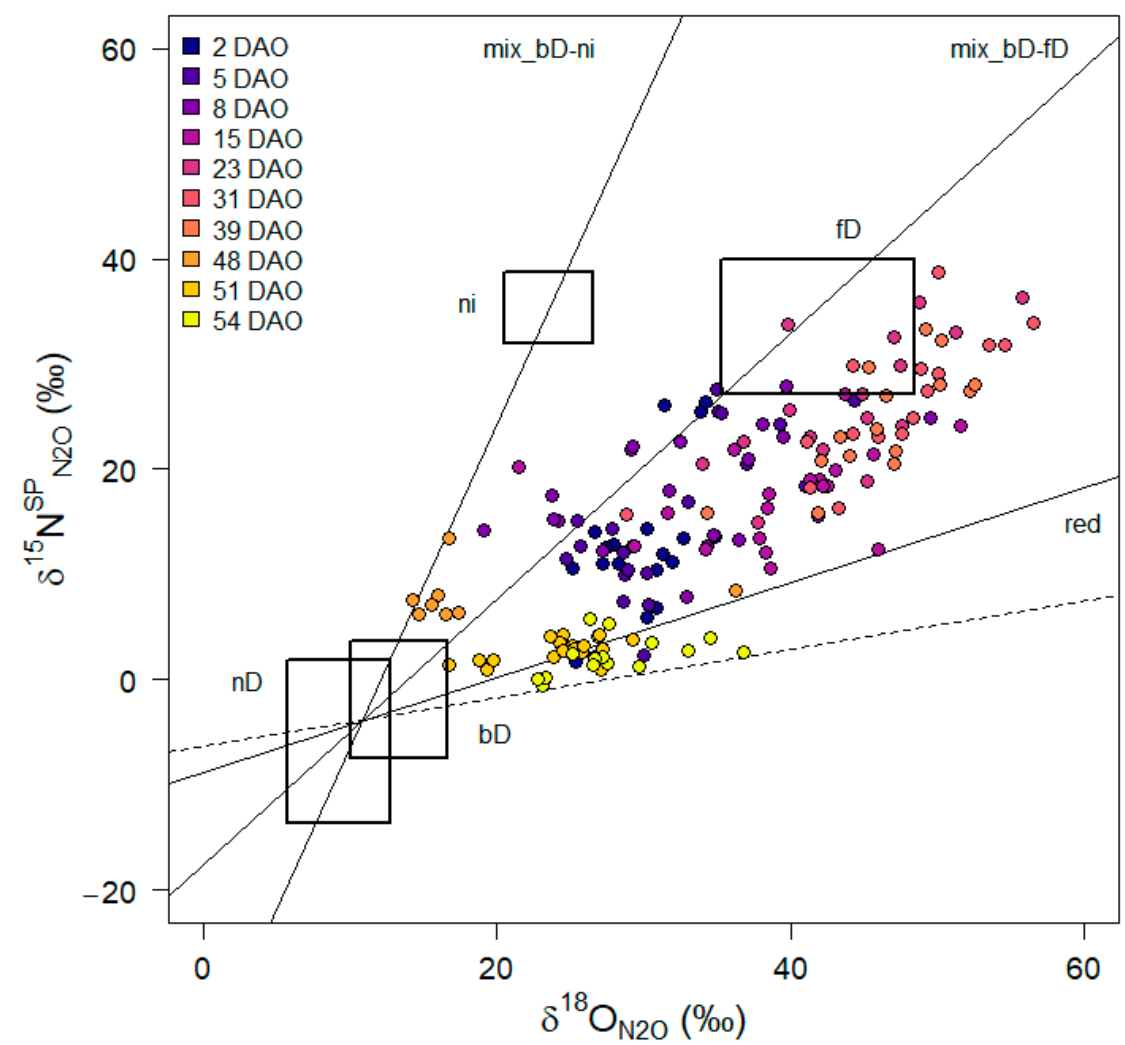

Figure 3. Isotopocule values of soil-emitted $\mathrm{N}_{2} \mathrm{O}$ per day plotted in the isotopocule map based on Lewicka-Szczebak et al. (2017) [22] and Yu et al. (2020) [23]. Boxes indicate the mean ranges for end-member values of $\delta^{15} \mathrm{~N}^{\mathrm{SP}}{ }_{\mathrm{N} 2 \mathrm{O}}$ and $\delta^{18} \mathrm{O}_{\mathrm{N} 2 \mathrm{O}}$ (corrected for $\delta^{18} \mathrm{O}_{\mathrm{H} 2 \mathrm{O}}$ ) for heterotrophic bacterial denitrification $(\mathrm{bD})$, nitrifier denitrification $(\mathrm{nD})$, nitrification $(\mathrm{ni})$, and fungal denitrification (fD) (view Table S1 for details). The mixing line connects the mean values of bD and fD (mix_bD-fD) or bD and ni (mix_bD-ni), respectively. The slope of the reduction lines (red) is based on the isotopic fractionation factor associated with $\mathrm{N}_{2} \mathrm{O}$ reduction to $\mathrm{N}_{2}$. Dashed line represents the minimum reduction line ( $\mathrm{n}=178$, oxic incubation conditions from $0 \mathrm{DAO}$ to $46 \mathrm{DAO}$, anoxic incubation conditions from $47 \mathrm{DAO}$ to $55 \mathrm{DAO})$. 
$\delta^{15} \mathrm{~N}_{\text {bulk }}$ and $\delta^{18} \mathrm{O}_{\mathrm{N} 2 \mathrm{O}}$ of soil-emitted $\mathrm{N}_{2} \mathrm{O}$ followed a similar pattern. Both values increased slightly during anoxic incubation (Figures 4 and S6). With onset of anoxic conditions, both $\delta^{15} \mathrm{~N}_{\text {bulk }}$ and $\delta^{18} \mathrm{O}_{\mathrm{N} 2 \mathrm{O}}$ decreased strongly and increased again until the end of the experiment.

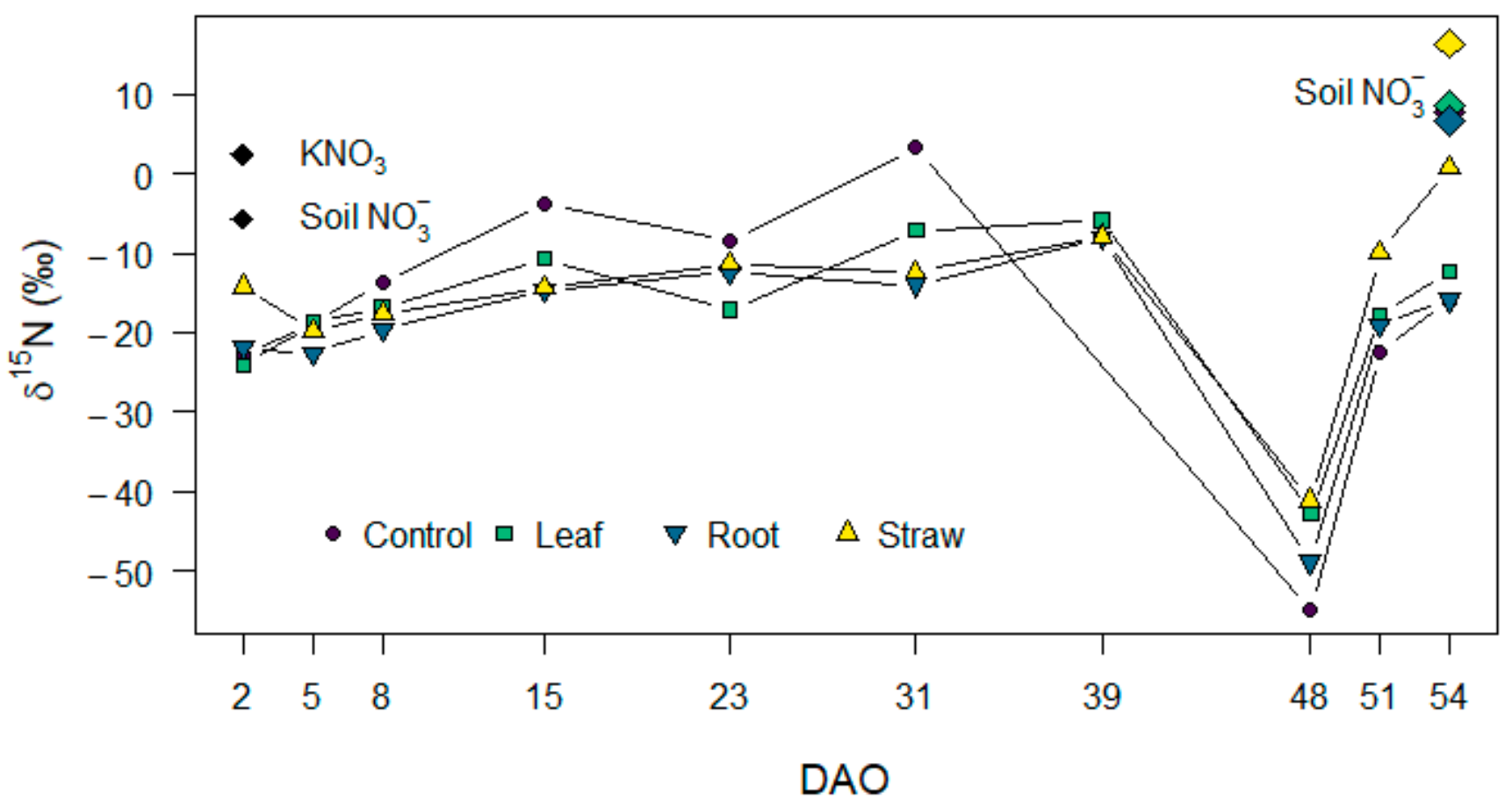

Figure 4. $\delta^{15} \mathrm{~N}_{\text {bulk }}$ of $\mathrm{N}_{2} \mathrm{O}$ (colored symbols and lines), added $\mathrm{KNO}_{3}$ and soil $\mathrm{NO}_{3}{ }^{-}$at first day of incubation (black symbols) and soil $\mathrm{NO}_{3}{ }^{-}$at last day of incubation (colored symbols with black borders) (means for $\mathrm{n}=5, \mathrm{n}=4$ for Control).

$\mathrm{fbD}$ and $\mathrm{rN}_{2} \mathrm{O}$ values exhibited similar patterns for mixing between heterotrophic bacterial denitrification/nitrifier denitrification and nitrification or fungal denitrification (Figure 5a,b, Supplementary Figure S6). After onset of incubation, the fraction of soilemitted $\mathrm{N}_{2} \mathrm{O}$ from heterotrophic bacterial denitrification/nitrifier denitrification (fbD, Figure 5a) was in tendency higher in maize litter treatments compared to Control. While $\mathrm{fbD}$ decreased in maize litter treatments during the oxic incubation period, it increased in Control without litter addition. With onset of anoxic incubation conditions, fbD increased strongly in all treatments, reaching values $>0.9$, indicating that bacterial denitrification became the dominant process under anoxic incubation conditions. The residual, unreduced $\mathrm{N}_{2} \mathrm{O}$ fraction $\left(\mathrm{rN}_{2} \mathrm{O}\right.$, Figure $\left.5 \mathrm{~b}\right)$ was mostly $<0.5$ and decreased during the oxic incubation phase, highlighting the significance of $\mathrm{N}_{2} \mathrm{O}$ reduction. On $51 \mathrm{DAO}, \mathrm{rN}_{2} \mathrm{O}$ was highest and decreased until 54 DAO. 

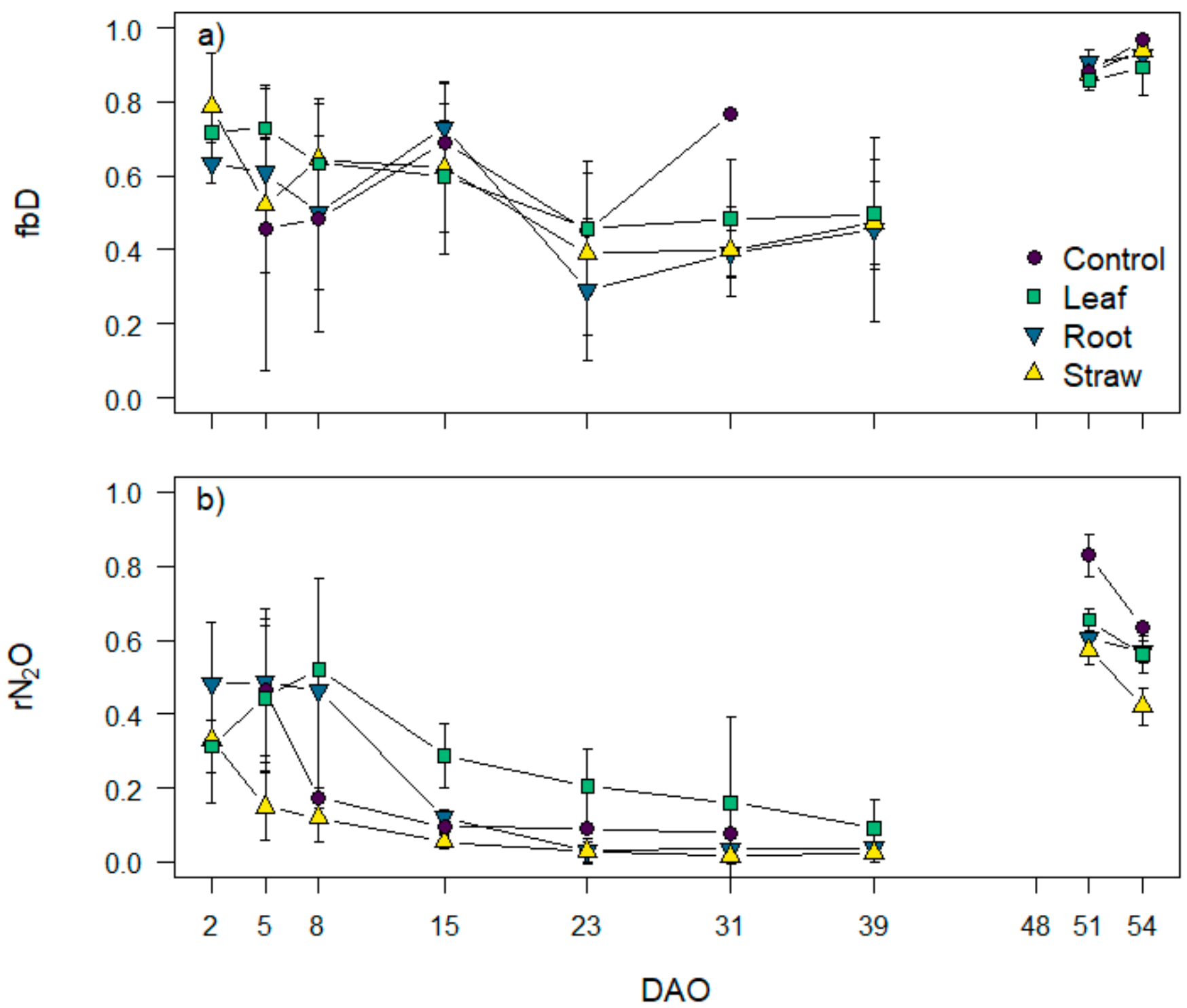

Figure 5. (a) Fraction of $\mathrm{N}_{2} \mathrm{O}$ originating from heterotrophic bacterial denitrification/nitrifier denitrification (fbD) and (b) fraction of residual unreduced $\mathrm{N}_{2} \mathrm{O}\left(\mathrm{rN}_{2} \mathrm{O}\right)$. Values were calculated based on the isotopocule mapping approach by Lewicka-Szczebak et al. (2017) [22] and represent results for scenario 1 (reduction-mixing) of bacterial denitrification with fungal denitrification (mean and standard deviation for $\mathrm{n}=5, \mathrm{n}=4$ for Control, data points missing for samples with an isotopic signature outside the reduction-mixing area, no $\mathrm{N}_{2} \mathrm{O}$ emitted from Control on $39 \mathrm{DAO}$ ).

\subsection{Interactions between $C$ and $N$ Availability and $N$ Fluxes}

To test the effect of $\mathrm{C}$ availability and SOM turnover on $\mathrm{N}$ fluxes and cumulative emissions, simple linear regression models were tested (Table 3).

The relationship between hourly $\mathrm{NO}+\mathrm{N}_{2} \mathrm{O}$ and $\mathrm{CO}_{2}$ fluxes was very weak during the oxic incubation phase (adj. $\mathrm{R}^{2}=0.08, p<0.001$, Table 3). In contrast, $\mathrm{NO}+\mathrm{N}_{2} \mathrm{O}+\mathrm{N}_{2}$ fluxes were highly positively correlated with $\mathrm{CO}_{2}$ fluxes during the anoxic incubation period (adj. $\mathrm{R}^{2}=0.86, p<0.001$, Table 3 ). Similarly, fbD and $\mathrm{rN}_{2} \mathrm{O}$ were positively correlated with total $\mathrm{CO}_{2}$ flux from soil, but the relationship was weak (adj. $\mathrm{R}^{2}=0.23$ and 0.31 , respectively, $p<0.001$, Table 3).

Cumulative anoxic $\mathrm{N}$ emissions $\left(\mathrm{NO}+\mathrm{N}_{2} \mathrm{O}+\mathrm{N}_{2}\right)$ were significantly positively correlated with total litter $\mathrm{C}$ input (adj. $\mathrm{R}^{2}=0.51, p<0.001$, Table 3). Furthermore, we found a significant negative correlation between the ratio of cumulative $\mathrm{N}_{2} \mathrm{O} /\left(\mathrm{N}_{2} \mathrm{O}+\mathrm{N}_{2}\right)$ emissions during anoxic incubation and the ratio of water-soluble $\mathrm{C}: \mathrm{N}$ of maize litter types (adj. 
$\mathrm{R}^{2}=0.51, p<0.001$, Table 3) and also with the soil $\mathrm{NO}_{3}{ }^{-}:$WEOC ratio at the end of the experiment (adj. $R^{2}=0.41, p<0.01$, Table 3). When standardized against $C$ input from litter, total cumulative $\mathrm{N}$ emissions did not differ between litter treatments (Supplementary Table S2).

\section{Discussion}

\subsection{Maize Litter Quality Controls N Mineralization}

Soil mineral N content, mineralization, and immobilization strongly depended on maize litter quality. In Control without litter addition, soil $\mathrm{NH}_{4}{ }^{+}$content decreased, but soil $\mathrm{NO}_{3}{ }^{-}$content strongly increased due to mineralization and nitrification of soil organic $\mathrm{N}$. Tillage often leads to increased soil mineral $\mathrm{N}$ content [40,41], and net $\mathrm{N}$ mineralization from control soils without litter addition has been reported [8,13,42]. In Leaf and Root, mineralization was higher than in Control as additional organic $\mathrm{N}$ from litter was mineralized. In contrast, addition of maize straw immobilized $\mathrm{N}$, which coincides with the higher C:N ratio in Straw compared to Leaf and Root. In general, immobilization of $\mathrm{N}$ follows the addition of litter with C:N ratios $>25: 1$ [7]. Net $\mathrm{N}$ mineralization after addition of maize roots is in contrast to most other studies reporting net $\mathrm{N}$ immobilization after addition of maize roots $[8,13,42,43]$. However, we used maize roots grown in a nutrient solution, which had higher total and water-soluble $\mathrm{N}$ content than those reported in other studies [13,44].

\subsection{Effect of Maize Litter Quality on $\mathrm{CO}_{2}$ Emissions and Priming Effect}

After onset of incubation, both litter and SOM-derived $\mathrm{CO}_{2}$ fluxes strongly increased in litter treatments, while $\mathrm{CO}_{2}$ efflux in Control was stable. Total cumulative $\mathrm{CO}_{2}$ emissions increased with increasing input of total and water-soluble $\mathrm{C}$, indicating that decomposition dynamics were controlled by the amount and quality of added plant material. The chemical composition of plant litter is known to be a primary controller of decomposition rates of both roots $[11,12,15]$ and aboveground plant litter $[4,10]$.

Especially during the first week after litter addition, SOM turnover was increased in all litter treatments, leading to a positive priming effect. The highest increase in SOM turnover was observed after addition of maize leaves which were characterized by high amounts of easily degradable compounds as indicated by high shares of carboxyl C (i.e., organic acids, amino acids) and alkyl C (i.e., fatty acids, amino acids, paraffines) [45]. Litter and $\mathrm{SOM}$-derived $\mathrm{CO}_{2}$ fluxes followed the same pattern and were highly positively correlated confirming that litter and SOM turnover are interrelated. Thus, our results are in accordance with the concept that litter with high degradability increases SOM turnover leading to a positive priming effect [17-19].

\subsection{Effect of Litter Quality and N Mineralization on N Emissions and Production Pathways under Oxic Atmosphere}

Directly after onset of oxic incubation, NO fluxes were highest in Control and Root while $\mathrm{N}_{2} \mathrm{O}$ fluxes were higher in litter amended treatments than in Control. The ratio of $\mathrm{NO} / \mathrm{N}_{2} \mathrm{O}$ can be used as an indicator whether $\mathrm{NO}$ is produced from nitrification or denitrification $[46,47]$. While the $\mathrm{NO} / \mathrm{N}_{2} \mathrm{O}$ emission ratio of bacterial denitrification is mostly around 0.01 , the emission ratios of $\mathrm{NO} / \mathrm{N}_{2} \mathrm{O}$ from nitrification are often higher than 1 [47]. In our study, the emission ratio of $\mathrm{NO} / \mathrm{N}_{2} \mathrm{O}$ was highest during the first 10 days after onset of incubation, with maximum values of 0.47 in Control indicating a high contribution of nitrification to NO formation. Analysis of soil samples taken prior to the onset of incubation revealed high $\mathrm{NH}_{4}{ }^{+}$content of soil, which further supports that nitrification contributed to $\mathrm{NO}$ emissions during the initial incubation phase. In Straw, where $\mathrm{N}$ was immobilized to decompose $\mathrm{C}$ compounds, $\mathrm{NO}$ fluxes decreased faster and were lower than in all other treatments. Furthermore, oxic cumulative $\mathrm{NO}$ emissions strongly decreased with increasing litter C: $\mathrm{N}$ ratio (adj. $\mathrm{R}^{2}=0.86, p<0.001$ ) and increased with increasing $\mathrm{N}$ mineralization (adj. $\mathrm{R}^{2}=0.57, p<0.001$ ) confirming that litter quality affected nitrification-derived $\mathrm{NO}$ emissions in the beginning of the oxic incubation phase. 
Addition of maize litter increased $\mathrm{N}_{2} \mathrm{O}$ fluxes compared to non-amended Control. As first, the headspace atmosphere had to be replaced by the mixture of $\mathrm{He} / \mathrm{O}_{2}$, measurements started approximately one day after onset of incubation conditions. At this time, decreasing $\mathrm{N}_{2} \mathrm{O}$ fluxes indicated that $\mathrm{N}_{2} \mathrm{O}$ fluxes had peaked within $24 \mathrm{~h}$ after water and $\mathrm{NO}_{3}{ }^{-}$ addition. After this initial increase, $\mathrm{N}_{2} \mathrm{O}$ fluxes decreased rapidly and then stayed on a similar level throughout the oxic phase. Immediately after onset of the incubation, bacterial denitrification (i.e., heterotrophic bacterial denitrification and nitrifier denitrification) was the dominant $\mathrm{N}_{2} \mathrm{O}$ emitting process in litter-amended treatments as indicated by the fraction of bacterial denitrification $(\mathrm{fbD})>0.6$. Gradually decreasing fbD values then indicate a shift towards nitrification or fungal denitrification. Litter addition $[27,48]$ and soil moisture of $70 \%$ WFPS may have promoted fungi, which often contribute to denitrification under weakly anoxic conditions $[49,50]$. Several studies have described a shift from bacterial to fungal dominance with ongoing incubations [27,51-53]. However, nitrification may have contributed to $\mathrm{N}_{2} \mathrm{O}$ formation in Root and Leaf as indicated by high mineralization and $\mathrm{NO} / \mathrm{N}_{2} \mathrm{O}$ ratio. In Control, nitrification presumably contributed to $\mathrm{N}_{2} \mathrm{O}$ formation, especially during the first days of the experiment, when $\mathrm{fbD}$ was $<0.3$ and the $\mathrm{NO} / \mathrm{N}_{2} \mathrm{O}$ ratio was high.

$\mathrm{rN}_{2} \mathrm{O}$ values were mostly $<0.5$, highlighting the significance of $\mathrm{N}_{2} \mathrm{O}$ reduction, also during the oxic incubation period. Thus, although $\mathrm{N}_{2}$ fluxes were lower than the detection limit of our incubation system $\left(5.5 \mu \mathrm{g} \mathrm{N}-\mathrm{N} \mathrm{kg}^{-1} \mathrm{~h}^{-1}\right)$, they significantly contributed to gaseous $\mathrm{N}$ losses. $\mathrm{N}_{2} \mathrm{O}$ reduction to $\mathrm{N}_{2}$ is the last step of denitrification [54] and it usually takes place when availability of $\mathrm{NO}_{x}$ is limited [55]. Furthermore, pore size and distribution, and soil moisture may affect $\mathrm{N}_{2} \mathrm{O}$ reduction to $\mathrm{N}_{2}$, as they control diffusion of $\mathrm{O}_{2}$ and $\mathrm{N}_{2} \mathrm{O}$ in soil $[20,56]$. Accordingly, for interpretation of the isotopocule mapping approach in our experiment, we think that the reduction-mixing scenario is more plausible: $\mathrm{N}_{2} \mathrm{O}$ was produced by denitrifying bacteria and partly reduced to $\mathrm{N}_{2}$ in anoxic microsites, and then $\mathrm{N}_{2} \mathrm{O}$ diffusing out of these hotspots was mixed with $\mathrm{N}_{2} \mathrm{O}$ from nitrification and fungal denitrification [57]. We anticipate that nitrification contributed to $\mathrm{N}_{2} \mathrm{O}$ formation when mineralization was high, while fungal denitrification became more important in litter-amended treatments with ongoing incubation.

\subsection{Effect of Maize Litter Quality and Mineralization on Potential Denitrification}

With onset of anoxic incubation conditions on $47 \mathrm{DAO}$, total $\mathrm{NO}$ and $\mathrm{N}_{2} \mathrm{O}$ fluxes increased rapidly, while $\mathrm{N}_{2}$ fluxes increased more slowly. $\delta^{18} \mathrm{O}_{\mathrm{N} 2 \mathrm{O}}$ of $\mathrm{N}_{2} \mathrm{O}$ emitted on $48 \mathrm{DAO}$ falls in the range of heterotrophic bacterial denitrification reported in earlier studies [23], indicating that heterotrophic bacterial denitrification was the main $\mathrm{N}_{2} \mathrm{O}$-emitting process with low reduction to $\mathrm{N}_{2}$. Interestingly, the $\delta^{15} \mathrm{~N}^{\text {bulk }}$ values on $48 \mathrm{DAO}$ strongly deviated from measured $\delta^{15} \mathrm{~N}^{\text {bulk }}$ values on all other sampling days and were slightly outside the reported endmember values of heterotrophic bacterial denitrification. Under oxic conditions, denitrification mostly took place in anoxic hotspots where ongoing reduction led to a fractionation in the $\mathrm{NO}_{3}{ }^{-}$pool undergoing denitrification, which is reflected in gradually increasing $\delta^{15} \mathrm{~N}^{\text {bulk }}$ values. With onset of anoxic conditions, previously unreduced $\mathrm{NO}_{3}{ }^{-}$contributed to $\mathrm{N}_{2} \mathrm{O}$ formation leading to a shift towards more negative $\delta^{15} \mathrm{~N}^{\text {bulk }}$ values $[29,58]$. When the contribution of pools with different $\mathrm{N}$ dynamics changes, shifts in the isotopic signature have been reported [59-61]. For our study, low $\delta^{15} \mathrm{~N}^{\text {bulk }}$ values on $48 \mathrm{DAO}$ are consistent with very high $\mathrm{N}_{2} \mathrm{O}$ fluxes and the low measured $\mathrm{N}_{2} \mathrm{O} /\left(\mathrm{N}_{2} \mathrm{O}+\mathrm{N}_{2}\right)$ ratio on 48 DAO leading to strong fractionation effects.

Analysis of $\delta^{15} \mathrm{~N}$ and $\delta^{18} \mathrm{O}$ in soil $\mathrm{NO}_{3}{ }^{-}$may improve accuracy of the $\mathrm{N}_{2} \mathrm{O}$ mapping approach and estimation of $\mathrm{N}_{2} \mathrm{O}$ formation processes [23]. $\delta^{15} \mathrm{~N}_{\mathrm{NO} 3}$ was higher at the end of the experiment compared to initial soil $\mathrm{NO}_{3}{ }^{-}$and added $\mathrm{KNO}_{3}$, confirming the ongoing fractionation during the reduction of the soil $\mathrm{NO}_{3}{ }^{-}$pool. Furthermore, $\delta^{15} \mathrm{~N}_{\mathrm{NO}}$ increased with decreasing mineralization, indicating a higher share of added $\mathrm{KNO}_{3}$ to residual $\mathrm{NO}_{3}{ }^{-}$at the end of the incubation experiment. Higher $\delta^{18} \mathrm{O}$ in Straw and Root may point towards a higher contribution of fungal denitrification, which is consistent with 
the higher contribution of fungi to decomposition of plant materials rich in celluloses and lignin $[16,27]$. Overall, it needs to be taken into account, that estimating $\mathrm{N}_{2} \mathrm{O}$ formation processes based on $\mathrm{N}_{2} \mathrm{O}$ isotopomers is subject to large uncertainties. Endmember values, reduction and fractionation factors have been obtained under differing incubation and environmental conditions, and may thus lead to over or underestimation of contributing processes $[57,61,62]$.

\subsection{Interaction between C Turnover and Denitrification}

In agricultural soils, denitrification is often controlled by the availability of readily decomposable organic matter with increasing $\mathrm{C}$ availability leading to increased $\mathrm{N}$ losses $[6,13,14,63,64]$. In contrast, we measured low denitrification derived $\mathrm{N}$ fluxes under oxic conditions, and the correlation between oxic $\mathrm{N}$ and $\mathrm{CO}_{2}$ fluxes was very weak indicating that denitrification was not directly affected by litter decomposition in our study. Although soil $\mathrm{NO}_{3}{ }^{-}$content was high and high litter and SOM turnover confirmed high $\mathrm{C}_{\text {org }}$ availability, $\mathrm{N}_{2} \mathrm{O}$ fluxes were very low, indicating that conditions for denitrifying microorganisms were not optimal. Rohe et al. (2021) [65] reported very low $\mathrm{N}_{2} \mathrm{O}+\mathrm{N}_{2}$ fluxes from an incubation study with the same soil at 60\% WFPS and higher fluxes compared to our study for 75 and $85 \%$ WFPS. Thus, our incubation conditions with a soil moisture of $70 \%$ WFPS may have been too low to promote denitrifying soil microorganisms. With onset of anoxic conditions, $\mathrm{N}$ fluxes increased immediately, confirming that high $\mathrm{pO}_{2}$ was restricting denitrification during the oxic incubation phase. In contrast to our expectations, the microbial respiration of litter and SOM did not promote the formation of litter associated anoxic hotspots for denitrification as high $\mathrm{O}_{2}$ diffusivity limited denitrification $[65,66]$.

In contrast, $\mathrm{N}$ and $\mathrm{CO}_{2}$ fluxes were highly positively correlated (adj. $\mathrm{R}^{2}=0.86$, $p<0.001$ ) under anoxic conditions, and cumulative $\mathrm{N}$ emissions increased with increasing litter $C$ input (adj. $\mathrm{R}^{2}=0.51, p<0.001$ ) confirming our hypothesis that higher $\mathrm{C}$ availability leads to increased gaseous $\mathrm{N}$ losses. However, this effect was based on the role of $\mathrm{C}$ as energy source for denitrifiers, as the potential $\mathrm{O}_{2}$ consumption by $\mathrm{C}$ decomposition was not relevant under anoxic conditions.

The ratio of denitrification end products $\mathrm{N}_{2} \mathrm{O} /\left(\mathrm{N}_{2} \mathrm{O}+\mathrm{N}_{2}\right)$ decreased with increasing water-extractable $\mathrm{C}: \mathrm{N}$ ratio of litter (adj. $\mathrm{R}^{2}=0.73, p<0.001$ ) and increasing soil WEOC: $\mathrm{NO}_{3}{ }^{-}$ratio at the end of the experiment (adj. $\mathrm{R}^{2}=0.41, p<0.01$ ) confirming that the ratio of available $\mathrm{C}$ to oxidized $\mathrm{N}$ is a major control of denitrification product stoichiometry [67]. Immobilization of $\mathrm{N}$ after addition of maize straw with high $\mathrm{C}: \mathrm{N}$ ratio restricted $\mathrm{N}$ availability leading to higher $\mathrm{N}_{2} \mathrm{O}$ reduction to $\mathrm{N}_{2}$. However, as soil $\mathrm{NO}_{3}{ }^{-}$content was still very high ( $>70 \mathrm{mg} \mathrm{NO}_{3}{ }^{-}-\mathrm{N} \mathrm{kg}^{-1}$ in all treatments at the end of the incubation experiment), $\mathrm{N}_{2} \mathrm{O}$ was the dominant end product, as $\mathrm{NO}_{3}{ }^{-}$is preferentially used as electron acceptor and high soil $\mathrm{NO}_{3}{ }^{-}$content can inhibit the reduction of $\mathrm{N}_{2} \mathrm{O}$ to $\mathrm{N}_{2}[27,67]$.

\section{Conclusions}

We investigated the effect of different maize litter types (young leaves and roots, straw) on $\mathrm{CO}_{2}, \mathrm{NO}, \mathrm{N}_{2} \mathrm{O}$, and $\mathrm{N}_{2}$ emissions under oxic and anoxic conditions in a laboratory incubation study. Addition of maize litter increased litter and $\mathrm{SOM}$ derived $\mathrm{CO}_{2}$ emissions, leading to a positive priming effect. SOM priming was highest after addition of maize leaves with a high share of easily degradable $\mathrm{C}$ compounds during the first week after onset of incubation. Although litter and SOM turnover were high, $\mathrm{NO}$ and $\mathrm{N}_{2} \mathrm{O}$ fluxes were low under oxic conditions as high $\mathrm{O}_{2}$ diffusivity limited denitrification.

The $\mathrm{NO} / \mathrm{N}_{2} \mathrm{O}$ ratio indicated that nitrification contributed to $\mathrm{NO}$ and $\mathrm{N}_{2} \mathrm{O}$ formation during the first two weeks of incubation, especially in Control without litter addition. In the litter-amended treatments, isotopocule mapping revealed that bacterial denitrification dominated $\mathrm{N}_{2} \mathrm{O}$ formation in the beginning of the incubation experiment with a subsequent shift towards fungal denitrification. With onset of anoxic incubation conditions after 47 days, $\mathrm{N}$ fluxes strongly increased and heterotrophic bacterial denitrification became the dominating source of $\mathrm{N}_{2} \mathrm{O}$. The $\mathrm{N}_{2} \mathrm{O} /\left(\mathrm{N}_{2} \mathrm{O}+\mathrm{N}_{2}\right)$ ratio decreased with increasing litter 
C:N ratio and $\mathrm{C}_{\text {org }}: \mathrm{NO}_{3}{ }^{-}$ratio in soil confirming that the ratio of available $\mathrm{C}: \mathrm{N}$ is a major control of denitrification product stoichiometry.

Supplementary Materials: The following are available online at https://www.mdpi.com/article/10.3 390/app11115309/s1, Figure S1a-c: Solid state ${ }^{13}$ C-CPMAS NMR spectra of maize litter used in the incubation experiment, Figure S2: $\delta^{13} \mathrm{C}$ of $\mathrm{CO}_{2}$ derived from maize litter, Figure S3: Total $\mathrm{CO}_{2}$ efflux from soil during oxic and anoxic incubation, Figure $44 a: \delta^{13} \mathrm{C}$ of $\mathrm{CO}_{2}$ evolving from soil and b: fraction of litter-derived $\mathrm{CO}_{2}$, Figure S5: $\mathrm{NO} / \mathrm{N}_{2} \mathrm{O}$ ratio during oxic and anoxic incubation, Figure S6: $\delta^{18} \mathrm{O}$ of $\mathrm{N}_{2} \mathrm{O}$, added $\mathrm{KNO}_{3}$, and soil $\mathrm{NO}_{3}{ }^{-}$at first and last day of incubation, Figure S7a: Fraction of $\mathrm{N}_{2} \mathrm{O}$ originating from heterotrophic bacterial denitrification/nitrifier denitrification and $\mathrm{b}+\mathrm{c}$ : fraction of

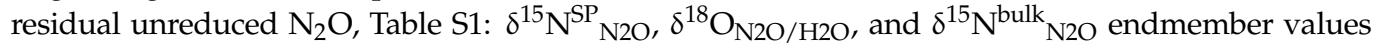
from literature used for isotopocule mapping, Table S2: Cumulative $\mathrm{CO}_{2}, \mathrm{NO}, \mathrm{N}_{2} \mathrm{O}$, and $\mathrm{N}_{2}$ emissions and denitrification product ratio standardized against litter $\mathrm{C}$ input.

Author Contributions: Conceptualization: P.S.R., R.W., J.P., and K.D., methodology (incubation system): P.S.R., B.P., K.D.; investigation: P.S.R.; data analysis: P.S.R.; data validation: P.S.R., R.W. and J.P.; writing—original draft preparation: P.S.R.; writing—review and editing: P.S.R., R.W., J.P., B.P., and K.D.; visualization: P.S.R.; supervision: R.W., J.P, and K.D.; funding acquisition: K.D. All authors have read and agreed to the published version of the manuscript.

Funding: This research work was supported by the Deutsche Forschungsgemeinschaft through the research unit DFG-FOR 2337: Denitrification in Agricultural Soils: Integrated Control and Modelling at Various Scales (DASIM, grant number DI 546/4-1). The APC was funded by the University of Göttingen.

Institutional Review Board Statement: Not applicable.

Informed Consent Statement: Not applicable.

Data Availability Statement: The datasets from this study can be found at https:// doi.org/10.25625 /FKSRMX.

Acknowledgments: We thank Simone Urstadt and Justus Detring for experimental and laboratory assistance and Jürgen Böttcher for soil classification. We acknowledge the Centre for Stable Isotope Research and Analysis of the University of Göttingen for all isotopic analyses, Jan Reent Köster for help with NO analysis, and Carsten W. Mueller for ${ }^{13} \mathrm{C}$-CPMAS NMR analyses. Further, we thank Ronny Surey for discussions about plant litter effects under anoxic conditions.

Conflicts of Interest: The authors declare no conflict of interest. The funders had no role in the design of the study; in the collection, analyses, or interpretation of data; in the writing of the manuscript, or in the decision to publish the results.

\section{References}

1. Baggs, E.M.; Rees, R.M.; Smith, K.A.; Vinten, A.J.A. Nitrous oxide emission from soils after incorporating crop residues. Soil Use Manag. 2000, 16, 82-87. [CrossRef]

2. Chen, H.; Li, X.; Hu, F.; Shi, W. Soil nitrous oxide emissions following crop residue addition: A meta-analysis. Glob. Chang. Biol. 2013, 19, 2956-2964. [CrossRef]

3. Johnson, J.M.-F.; Barbour, N.W.; Weyers, S.L. Chemical Composition of Crop Biomass Impacts Its Decomposition. Soil Sci. Soc. Am. J. 2007, 71, 155-162. [CrossRef]

4. Zhang, D.; Hui, D.; Luo, Y.; Zhou, G. Rates of litter decomposition in terrestrial ecosystems: Global patterns and controlling factors. J. Plant Ecol. 2008, 1, 85-93. [CrossRef]

5. Li, X.; Hu, F.; Shi, W. Plant material addition affects soil nitrous oxide production differently between aerobic and oxygen-limited conditions. Appl. Soil Ecol. 2013, 64, 91-98. [CrossRef]

6. Millar, N.; Baggs, E.M. Chemical composition, or quality, of agroforestry residues influences $\mathrm{N}_{2} \mathrm{O}$ emissions after their addition to soil. Soil Biol. Biochem. 2004, 36, 935-943. [CrossRef]

7. Robertson, G.P.; Groffman, P.M. Nitrogen Transformations. In Soil Microbiology, Ecology and Biochemistry; Paul, E.A., Ed.; Acwdemic Press: Burlington, MA, USA, 2015; pp. 421-446. ISBN 9780128132692.

8. Velthof, G.L.; Kuikman, P.J.; Oenema, O. Nitrous oxide emission from soils amended with crop residues. Nutr. Cycl. Agroecosyst. 2002, 62, 249-261. [CrossRef]

9. Burford, J.R.; Bremner, J.M. Relationships between the denitrification capacities of soils and total, water-soluble and readily decomposable soil organic matter. Soil Biol. Biochem. 1975, 7, 389-394. [CrossRef] 
10. Jensen, L.S.; Salo, T.; Palmason, F.; Breland, T.A.; Henriksen, T.M.; Stenberg, B.; Pedersen, A.; Lundström, C.; Esala, M. Influence of biochemical quality on $\mathrm{C}$ and $\mathrm{N}$ mineralisation from a broad variety of plant materials in soil. Plant Soil 2005, 273, 307-326. [CrossRef]

11. Redin, M.; Guénon, R.; Recous, S.; Schmatz, R.; de Freitas, L.L.; Aita, C.; Giacomini, S.J. Carbon mineralization in soil of roots from twenty crop species, as affected by their chemical composition and botanical family. Plant Soil 2014, 378, 205-214. [CrossRef]

12. Silver, W.L.; Miya, R.K. Global patterns in root decomposition: Comparisons of climate and litter quality effects. Oecologia 2001, 129, 407-419. [CrossRef] [PubMed]

13. Rummel, P.S.; Pfeiffer, B.; Pausch, J.; Well, R.; Schneider, D.; Dittert, K. Maize root and shoot litter quality controls short-term $\mathrm{CO}_{2}$ and $\mathrm{N}_{2} \mathrm{O}$ emissions and bacterial community structure of arable soil. Biogeosciences 2020, 17, 1181-1198. [CrossRef]

14. Surey, R.; Schimpf, C.M.; Sauheitl, L.; Mueller, C.W.; Rummel, P.S.; Dittert, K.; Kaiser, K.; Böttcher, J.; Mikutta, R. Potential denitrification stimulated by water-soluble organic carbon from plant residues during initial decomposition. Soil Biol. Biochem. 2020. [CrossRef]

15. Birouste, M.; Kazakou, E.; Blanchard, A.; Roumet, C. Plant traits and decomposition: Are the relationships for roots comparable to those for leaves? Ann. Bot. 2012, 109, 463-472. [CrossRef] [PubMed]

16. Kögel-Knabner, I. The macromolecular organic composition of plant and microbial residues as inputs to soil organic matter. Soil Biol. Biochem. 2002, 34, 139-162. [CrossRef]

17. Six, J.; Jastrow, J.D. Organic Matter Turnover. In Encyclopedia of Soil Science; Lal, R., Ed.; Dekker: New York, NY, USA, 2002.

18. Kuzyakov, Y.; Bol, R. Sources and mechanisms of priming effect induced in two grassland soils amended with slurry and sugar. Soil Biol. Biochem. 2006, 38, 747-758. [CrossRef]

19. Rinkes, Z.L.; DeForest, J.L.; Grandy, A.S.; Moorhead, D.L.; Weintraub, M.N. Interactions between leaf litter quality, particle size, and microbial community during the earliest stage of decay. Biogeochemistry 2014, 117, 153-168. [CrossRef]

20. Kravchenko, A.N.; Toosi, E.R.; Guber, A.K.; Ostrom, N.E.; Yu, J.; Azeem, K.; Rivers, M.L.; Robertson, G.P. Hotspots of soil N2O emission enhanced through water absorption by plant residue. Nat. Geosci. 2017, 10, 496-500. [CrossRef]

21. Arcand, M.M.; Congreves, K.A. Elucidating microbial carbon utilization and nitrous oxide dynamics with ${ }^{13} \mathrm{C}$-substrates and $\mathrm{N}_{2} \mathrm{O}$ isotopomers in contrasting horticultural soils. Appl. Soil Ecol. 2020,147, 103401. [CrossRef]

22. Lewicka-Szczebak, D.; Augustin, J.; Giesemann, A.; Well, R. Quantifying $\mathrm{N}_{2} \mathrm{O}$ reduction to $\mathrm{N}_{2}$ based on $\mathrm{N}_{2} \mathrm{O}$ isotopoculesvalidation with independent methods (helium incubation and ${ }^{15} \mathrm{~N}$ gas flux method). Biogeosciences 2017, 14, 711-732. [CrossRef]

23. Yu, L.; Harris, E.; Lewicka-Szczebak, D.; Barthel, M.; Blomberg, M.R.A.; Harris, S.J.; Johnson, M.S.; Lehmann, M.F.; Liisberg, J.; Müller, C.; et al. What can we learn from $\mathrm{N}_{2} \mathrm{O}$ isotope data?-Analytics, processes and modelling. Rapid Commun. Mass Spectrom. 2020, 34, 1-14. [CrossRef] [PubMed]

24. Mengutay, M.; Ceylan, Y.; Kutman, U.B.; Cakmak, I. Adequate magnesium nutrition mitigates adverse effects of heat stress on maize and wheat. Plant Soil 2013, 368, 57-72. [CrossRef]

25. Köster, J.R.; Well, R.; Dittert, K.; Giesemann, A.; Lewicka-Szczebak, D.; Mühling, K.H.; Herrmann, A.; Lammel, J.; Senbayram, M. Soil denitrification potential and its influence on $\mathrm{N}_{2} \mathrm{O}$ reduction and $\mathrm{N}_{2} \mathrm{O}$ isotopomer ratios. Rapid Commun. Mass Spectrom. 2013, 27, 2363-2373. [CrossRef]

26. Scholefield, D.; Hawkins, J.M.B.B.; Jackson, S.M. Development of a helium atmosphere soil incubation technique for direct measurement of nitrous oxide and dinitrogen fluxes during denitrification. Soil Biol. Biochem. 1997, 29, 1345-1352. [CrossRef]

27. Senbayram, M.; Well, R.; Bol, R.; Chadwick, D.R.; Jones, D.L.; Wu, D. Interaction of straw amendment and soil $\mathrm{NO}_{3}{ }^{-} \mathrm{content}^{-}$ controls fungal denitrification and denitrification product stoichiometry in a sandy soil. Soil Biol. Biochem. 2018, 126, 204-212. [CrossRef]

28. Wang, R.; Willibald, G.; Feng, Q.; Zheng, X.; Liao, T.; Brüggemann, N.; Butterbach-Bahl, K. Measurement of $\mathrm{N}_{2}, \mathrm{~N}_{2} \mathrm{O}, \mathrm{NO}$, and $\mathrm{CO}_{2}$ emissions from soil with the gas-flow-soil-core technique. Environ. Sci. Technol. 2011, 45, 6066-6072. [CrossRef] [PubMed]

29. Lewicka-Szczebak, D.; Well, R.; Köster, J.R.; Fuß, R.; Senbayram, M.; Dittert, K.; Flessa, H. Experimental determinations of isotopic fractionation factors associated with $\mathrm{N}_{2} \mathrm{O}$ production and reduction during denitrification in soils. Geochim. Cosmochim. Acta 2014, 134, 55-73. [CrossRef]

30. Toyoda, S.; Yoshida, N. Determination of Nitrogen Isotopomers of Nitrous. Anal. Chem. 1999, 71, 4711-4718. [CrossRef]

31. Buchen, C.; Lewicka-Szczebak, D.; Flessa, H.; Well, R. Estimating $\mathrm{N}_{2} \mathrm{O}$ processes during grassland renewal and grassland conversion to maize cropping using $\mathrm{N}_{2} \mathrm{O}$ isotopocules. Rapid Commun. Mass Spectrom. 2018, 32, 1053-1067. [CrossRef] [PubMed]

32. Röckmann, T.; Kaiser, J.; Brenninkmeijer, C.A.M.; Brand, W.A. Gas chromatography /isotope-ratio mass spectrometry method for high-precision position-dependent ${ }^{15} \mathrm{~N}$ and ${ }^{18} \mathrm{O}$ measurements of atmospheric nitrous oxide. Rapid Commun. Mass Spectrom. 2003, 17, 1897-1908. [CrossRef] [PubMed]

33. Lewicka-Szczebak, D. Mapping approach model after Lewicka-Szczebak et al. (2017)-detailed description of calculation procedures. RG 2018. [CrossRef]

34. Casciotti, K.L.; Sigman, D.M.; Hastings, M.G.; Böhlke, J.K.; Hilkert, A. Measurement of the oxygen isotopic composition of nitrate in seawater and freshwater using the denitrifier method. Anal. Chem. 2002, 74, 4905-4912. [CrossRef]

35. Sigman, D.M.; Casciotti, K.L.; Andreani, M.; Barford, C.; Galanter, M.; Böhlke, J.K. A bacterial method for the nitrogen isotopic analysis of nitrate in seawater and freshwater. Anal. Chem. 2001, 73, 4145-4153. [CrossRef]

36. R Core Team R: A Language and Environment for Statistical Computing 2019. R version 3.6.0 - Planting of a Tree"; R Foundation for Statistical Computing: Vienna, Austria, 2019. 
37. Blackmon, H.; Adams, R.H. evobiR: Comparative and Population Genetic Analyses 2015. R Package Version 1.1; R Foundation for Statistical Computing: Vienna, Austria, 2015.

38. Zeileis, A.; Grothendieck, G. zoo: S3 Infrastructure for Regular and Irregular Time Series. J. Stat. Softw. 2005, 14, 1-27. [CrossRef]

39. Garnier, S. viridisLite: Default Color Maps from "matplotlib" (Lite Version) 2018. R Package Version 0.3.0; R Foundation for Statistical Computing: Vienna, Austria, 2018.

40. Höper, H. Carbon and nitrogen mineralisation rates of fens in Germany used for agriculture. In Wetlands in Central Europe; Broll, G., Merbach, W., Pfeiffer, E.M., Eds.; Springer: Berlin/Heidelberg, Germany, 2002; pp. 149-164. ISBN 978-3-662-05054-5.

41. Kristensen, H.L.; Debosz, K.; McCarty, G.W. Short-term effects of tillage on mineralization of nitrogen and carbon in soil. Soil Biol. Biochem. 2003, 35, 979-986. [CrossRef]

42. Machinet, G.E.; Bertrand, I.; Chabbert, B.; Recous, S. Decomposition in soil and chemical changes of maize roots with genetic variations affecting cell wall quality. Eur. J. Soil Sci. 2009, 60, 176-185. [CrossRef]

43. Mary, B.; Fresneau, C.; Morel, J.L.; Mariotti, A. C and N cycling during decomposition of root mucilage, roots and glucose in soil. Soil Biol. Biochem. 1993, 25, 1005-1014. [CrossRef]

44. Machinet, G.E.; Bertrand, I.; Barrière, Y.; Chabbert, B.; Recous, S. Impact of plant cell wall network on biodegradation in soil: Role of lignin composition and phenolic acids in roots from 16 maize genotypes. Soil Biol. Biochem. 2011, 43, 1544-1552. [CrossRef]

45. Knicker, H. Solid state CPMAS ${ }^{13} \mathrm{C}$ and ${ }^{15} \mathrm{~N}$ NMR spectroscopy in organic geochemistry and how spin dynamics can either aggravate or improve spectra interpretation. Org. Geochem. 2011, 42, 867-890. [CrossRef]

46. Cheng, W.; Tsuruta, H.; Chen, G.; Yagi, K. $\mathrm{N}_{2} \mathrm{O}$ and NO production in various Chinese agricultural soils by nitrification. Soil Biol. Biochem. 2004, 36, 953-963. [CrossRef]

47. Skiba, U.; Fowler, D.; Smith, K.A. Nitric oxide emissions from agricultural soils in temperate and tropical climates: Sources, controls and mitigation options. Nutr. Cycl. Agroecosyst. 1997, 48, 139-153. [CrossRef]

48. Chen, H.; Mothapo, N.V.; Shi, W. Fungal and bacterial $\mathrm{N}_{2} \mathrm{O}$ production regulated by soil amendments of simple and complex substrates. Soil Biol. Biochem. 2015, 84, 116-126. [CrossRef]

49. Hayatsu, M.; Tago, K.; Saito, M. Various players in the nitrogen cycle: Diversity and functions of the microorganisms involved in nitrification and denitrification. Soil Sci. Plant Nutr. 2008, 54, 33-45. [CrossRef]

50. Lavrent'ev, R.B.; Zaitsev, S.A.; Sudnitsyn, I.I.; Kurakov, A.V. Nitrous oxide production by fungi in soils under different moisture levels. Moscow Univ. Soil Sci. Bull. 2008, 63, 178-183. [CrossRef]

51. Laughlin, R.J.; Stevens, R.J. Evidence for Fungal Dominance of Denitrification and Codenitrification in a Grassland Soil. Soil Sci. Soc. Am. J. 2002, 66, 1540-1548. [CrossRef]

52. Wu, D.; Senbayram, M.; Well, R.; Brüggemann, N.; Pfeiffer, B.; Loick, N.; Stempfhuber, B.; Dittert, K.; Bol, R. Nitrification inhibitors mitigate $\mathrm{N}_{2} \mathrm{O}$ emissions more effectively under straw-induced conditions favoring denitrification. Soil Biol. Biochem. 2017, 104, 197-207. [CrossRef]

53. Zhong, L.; Bowatte, S.; Newton, P.C.D.; Hoogendoorn, C.J.; Luo, D. An increased ratio of fungi to bacteria indicates greater potential for $\mathrm{N}_{2} \mathrm{O}$ production in a grazed grassland exposed to elevated $\mathrm{CO}_{2}$. Agric. Ecosyst. Environ. 2018, 254, 111-116. [CrossRef]

54. Zumft, W.G. Cell biology and molecular basis of denitrification. Microbiol. Mol. Biol. Rev. 1997, 61, 533-616. [CrossRef] [PubMed]

55. Firestone, M.K.; Smith, M.S.; Firestone, R.B.; Tiedje, J.M. The Influence of Nitrate, Nitrite, and Oxygen on the Composition of the Gaseous Products of Denitrification in Soil. Soil Sci. Soc. Am. J. 1979, 43, 1140-1144. [CrossRef]

56. Schlüter, S.; Henjes, S.; Zawallich, J.; Bergaust, L.; Horn, M.; Ippisch, O.; Vogel, H.-J.; Dörsch, P. Denitrification in Soil Aggregate Analogues-Effect of Aggregate Size and Oxygen Diffusion. Front. Environ. Sci. 2018, 6, 1-10. [CrossRef]

57. Wu, D.; Well, R.; Cárdenas, L.M.; Fuß, R.; Lewicka-Szczebak, D.; Köster, J.R.; Brüggemann, N.; Bol, R. Quantifying N 2 O reduction to $\mathrm{N}_{2}$ during denitrification in soils via isotopic mapping approach: Model evaluation and uncertainty analysis. Environ. Res. 2019, 179, 1-6. [CrossRef]

58. Ostrom, N.E.; Piit, A.; Sutka, R.; Ostrom, P.H.; Grandy, A.S.; Huizinga, K.M.; Robertson, G.P. Isotopologue effects during $\mathrm{N}_{2} \mathrm{O}$ reduction in soils and in pure cultures of denitrifiers. J. Geophys. Res. Biogeosci. 2007, 112, 1-12. [CrossRef]

59. Bergstermann, A.; Cárdenas, L.; Bol, R.; Gilliam, L.; Goulding, K.; Meijide, A.; Scholefield, D.; Vallejo, A.; Well, R. Effect of antecedent soil moisture conditions on emissions and isotopologue distribution of $\mathrm{N}_{2} \mathrm{O}$ during denitrification. Soil Biol. Biochem. 2011, 43, 240-250. [CrossRef]

60. Cardenas, L.M.; Bol, R.; Lewicka-Szczebak, D.; Gregory, A.S.; Matthews, G.P.; Whalley, W.R.; Misselbrook, T.H.; Scholefield, D.; Well, R. Effect of soil saturation on denitrification in a grassland soil. Biogeosciences 2017, 14, 4691-4710. [CrossRef]

61. Lewicka-Szczebak, D.; Well, R.; Bol, R.; Gregory, A.S.; Matthews, G.P.; Misselbrook, T.; Whalley, W.R.; Cardenas, L.M. Isotope fractionation factors controlling isotopocule signatures of soil-emitted $\mathrm{N}_{2} \mathrm{O}$ produced by denitrification processes of various rates. Rapid Commun. Mass Spectrom. 2015, 29, 269-282. [CrossRef]

62. Lewicka-Szczebak, D.; Piotr Lewicki, M.; Well, R. $\mathrm{N}_{2} \mathrm{O}$ isotope approaches for source partitioning of $\mathrm{N}_{2} \mathrm{O}$ production and estimation of $\mathrm{N}_{2} \mathrm{O}$ reduction-validation with the ${ }^{15} \mathrm{~N}$ gas-flux method in laboratory and field studies. Biogeosciences 2020, 17, 5513-5537. [CrossRef]

63. Azam, F.; Müller, C.; Weiske, A.; Benckiser, G.; Ottow, J.C.G. Nitrification and denitrification as sources of atmospheric nitrous oxide-Role of oxidizable carbon and applied nitrogen. Biol. Fertil. Soils 2002, 35, 54-61. [CrossRef] 
64. Millar, N.; Baggs, E.M. Relationships between $\mathrm{N}_{2} \mathrm{O}$ emissions and water-soluble $\mathrm{C}$ and $\mathrm{N}$ contents of agroforestry residues after their addition to soil. Soil Biol. Biochem. 2005, 37, 605-608. [CrossRef]

65. Rohe, L.; Apelt, B.; Vogel, H.-J.; Well, R.; Wu, G.-M.; Schlüter, S. Denitrification in soil as a function of oxygen supply and demand at the microscale. Biogeosciences 2021, 1-32.

66. Schlüter, S.; Zawallich, J.; Vogel, H.J.; Dörsch, P. Physical constraints for respiration in microbial hotspots in soil and their importance for denitrification. Biogeosciences 2019, 16, 3665-3675. [CrossRef]

67. Firestone, M.K. Biological denitrification. In Nitrogen in Agricultural Soils, Agronomy Monograph; American Society of Agronomy, Inc.: Madison, WI, USA; Crop Science Society of America, Inc.: Madison, WI, USA; Soil Science Society of America, Inc.: Madison, WI, USA, 1982; Volume 22, pp. 289-326. [CrossRef] 